\title{
ASPECTOS TEXTURAIS DOS SEDIMENTOS QUATERNÁRIOS DA PLANÍCIE COSTEIRA DO SUL DO ESTADO DE SANTA CATARINA, BRASIL: REGIÃO DAS LAGOAS DOS ESTEVES, FAXINAL E MÃE LUZIA
}

Aline Pires Mateus ${ }^{1}$ Norberto Olmiro Horn Filho²

Resumo: As planícies costeiras se constituem de ambientes extremamente dinâmicos que comportam pacotes sedimentares de relevância para os estudos costeiros. Estes pacotes sedimentares denotam características dos agentes de transporte e dos ambientes de deposição, sendo estas características de fundamental importância para o conhecimento da história geológica local. Portanto, o objetivo deste trabalho é caracterizar, através da análise textural, os sedimentos quaternários e os ambientes deposicionais da planície costeira que representa o sistema deposicional laguna-barreira IV na região das lagoas dos Esteves, Faxinal e Mãe Luzia, sul do estado de Santa Catarina, Brasil. A poligonal de estudo compõese de uma área de barreira e uma área de retro barreira. Sendo a área de barreira composta por sedimentos arenosos oriunda de ambientes eólicos e marinhos, e a área de retro-barreira por sedimentos areno-lamosos de ambientes lagunares.

Palavras-chave: Planície costeira. Sedimentos. Textura. Lagunas. Sul de Santa Catarina.

\section{TEXTURAL ASPECTS OF THE QUATERNARY SEDIMENTS OF THE SOUTHERN SANTA CATARINA COASTAL PLAIN, BRAZIL: ESTEVES, FAXINAL AND MÃE LUZIA LAGOONS REGION}

\begin{abstract}
The coastal plains consist of extremely dynamic environments that contain sedimentary packages of relevance for the coastal studies. These sedimentary packages denote characteristics of the transport agents and the deposition environments, being these characteristics of fundamental importance for the knowledge of the local geological history. Therefore, the objective of this work is to characterize, through the textural analysis, the Quaternary sediments and depositional environments of the coastal plain that represents the depositional lagoon-barrier IV system in the lagoons of Esteves, Faxinal and Mãe Luzia, southern Santa Catarina, Brazil. The study polygon consists of a barrier area and a retro barrier area. The barrier area consists of sandy sediments from eolic and shallow marine environments, and the back barrier area by sand and mud sediments of lagoon environments.
\end{abstract}

Keywords: Coastal Plain. Sediments. Texture. Lagoons. Southern Santa Catarina.

\section{ASPECTOS TEXTURALES DE LOS SEDIMENTOS CUATERNARIOS DE LA COSTA SUR DEL LLANO DEL ESTADO DE SANTA CATARINA, BRASIL: REGIÓN LAGOAS DOS ESTEVES, FAXINAL Y MÃE LUZIA}

\footnotetext{
${ }^{1}$ Universidade Federal de Santa Catarina, Departamento de Geociências, Florianópolis. Brasil, apiresmatheus@gmail.com, https://orcid.org/0000-0001-5675-1629

2 Universidade Federal de Santa Catarina, Departamento de Geociências, Florianópolis. Brasil, norberto.horn@ufsc.br>, https://orcid.org/0000-0002-2173-7680
} 
Resumen: Las llanuras costeras son entornos extremadamente dinámicos que contienen paquetes sedimentarios de relevancia para los estudios costeros. Estos paquetes sedimentarios denotan características de los agentes de transporte y entornos de deposición, siendo estas características de fundamental importancia para el conocimiento de la historia geológica local. Por lo tanto, el objetivo de este trabajo es caracterizar, a través del análisis textural, los sedimentos cuaternarios y los ambientes deposicionales de la llanura costera que representa el sistema de deposición laguna-barrera IV en las lagunas Esteves, Faxinal y Mãe Luzia, en el sur del estado de Santa Catarina, Brasil. El polígono de estudio consta de un área de barrera y un área de barrera retro. Siendo el área de barrera compuesta por sedimentos arenosos de viento y ambientes marinos, y el área de barrera trasera por sedimentos de barro arenoso de ambientes de laguna.

Palabras clave: Llanura costera. Sedimento. Textura. Lagunas. Sur de Santa Catarina.

\section{Introdução}

O setor Sul da província costeira do estado de Santa Catarina apresenta características geológicas, geomorfológicas e oceanográficas que proporcionaram a formação de uma larga planície costeira composta por depósitos e fácies sedimentares atribuídos ao sistema deposicional do tipo laguna-barreira (HORN FILHO \& DIEHL, 1994; 2001; HORN FILHO, 2003; 2010; HORN FILHO \& FELIX, 2016).

O sistema deposicional laguna-barreira constitui-se de quatro sistemas, do mais antigo para o mais recente: laguna-barreira I, laguna-barreira II, laguna-barreira III e laguna-barreira IV (VILLWOCK et al., 1986). Os sistemas laguna-barreira I, II e III são de idade pleistocênica e o sistema laguna-barreira IV de idade holocênica, é neste último que que se situa a região das lagoas Esteves, Faxinal e Mãe Luzia, ambiente de estudo da presente pesquisa.

O sistema deposicional laguna-barreira IV se desenvolveu durante o Último Máximo Transgressivo (costa brasileira) à cerca de 5,1 Ka AP com nível do mar de $\pm 4 \mathrm{~m}$ acima do atual, deixando com a posterior regressão um complexo de lagoas costeiras atualmente separadas do oceano por barreiras arenosas ou ainda conexas por inlets (canais de ligação).

As barreiras costeiras são classificadas na literatura pelas escolas australiana (ROY et al., 1994; HESP \& SHORT, 1999) e americana (FISHER \& McGOWEN, 1969; BOYD et al., 1992; MORTON, 1994). De acordo com Roy et al. (1994), as barreiras costeiras servem como verdadeiras "barreiras" entre o continente e o 
oceano, sendo compostas por sedimentos depositados em ambientes praiais, de duna, de canal e delta de maré e como leques de sobrelavagem.

Os sedimentos que constituem as barreiras apresentam características granulométricas e composicionais essenciais para determinação dos ambientes deposicionais. Estas características serão aqui identificadas a partir da utilização de métodos clássicos e modernos. Portanto, esta pesquisa tem como função identificar os depósitos e suas características granulométricas e composicionais do sistema deposicional laguna-barreira IV, na região das lagoas Esteves, Faxinal e Mãe Luzia, sul do estado de Santa Catarina.

\section{Desenvolvimento}

A formação das planícies costeiras está diretamente relacionada às variações relativas do nível do mar que ocorreram durante o Cenozoico, pois implicaram em alterações da linha de costa (transgressões e regressões), as quais são reconhecidas por indicadores geológicos, geomorfológicos, biológicos e arqueológicos (MARTIN et al.,1986).

No Brasil os estudos sobre as variações relativas do nível do mar avançaram a partir da década de 1970. Foram desenvolvidos trabalhos nas planícies costeiras dos estados de São Paulo, Rio de Janeiro, Bahia, Sergipe, Alagoas, Espírito Santo, Paraná, Santa Catarina e Rio Grande do Sul, bem como estudos dos depósitos sedimentares nas desembocaduras dos rios São Francisco do Sul, Jequitinhonha, Paraíba do Sul e Doce.

Anterior ao trabalho de Suguio et al. (1985) (um dos estudos mais importantes sobre variações relativas do nível do mar na costa brasileira), Hartt (1870); Branner (1904); Freitas (1951); e Bigarella (1965), haviam realizado alguns estudos identificando oscilações da linha de costa brasileira, as quais eram atribuídas ao Terciário. Embora, posteriormente, serem reconhecidas como do período Quaternário.

Os trabalhos desenvolvidos por Suguio et al. (1985), nas regiões costeiras supracitadas, exceto o estado do Rio Grande do Sul, foram realizados utilizando como indicadores dados geológicos, biológicos e pré-históricos. Em todos os setores do litoral brasileiro estudados por Suguio et al. (1985), houve avanço do nível relativo do mar (NRM) durante o Holoceno, com elevação máxima em 5,1 Ka AP. 
Para a costa do Rio Grande do Sul, Villwock et al. (1986), relacionaram as oscilações do NRM com o sistema deposicional do tipo laguna-barreira. Segundo o autor ocorreram no mínimo quatro ciclos transgressivos-regressivos de idades pleistocênica e holocênica.

Um sistema deposicional caracteriza-se por uma "assembleia tridimensional de litofácies interligadas geneticamente por processos e ambientes ativos (sistemas deposicionais modernos) ou inferidos (sistemas deposicionais antigos)" (FISHER \& McGOWEN, 1967). O sistema deposicional do tipo laguna-barreira (VILLWOCK et al., 1986) constitui-se de fácies sedimentares moldadas por processos internos e externos (comportamento tectônico, variações climáticas e flutuações do nível relativo do mar durante o Cenozoico).

Na planície costeira do Rio Grande do Sul foram reconhecidos quatro sistemas laguna-barreira (I, II, III e IV) (VILLWOCK et al., 1986) (Figura 1), e na planície costeira análoga de Santa Catarina três sistemas laguna-barreira (II, III e IV) (HORN FILHO, 2003, 2010a). Cada sistema representa o máximo de uma transgressão, seguida de uma regressão. O sistema deposicional do tipo lagunabarreira é composto por três subsistemas relacionados geneticamente (Figura 2).

Figura 1: llustração do sistema laguna-barreira para a planície costeira do Rio Grande do Sul.

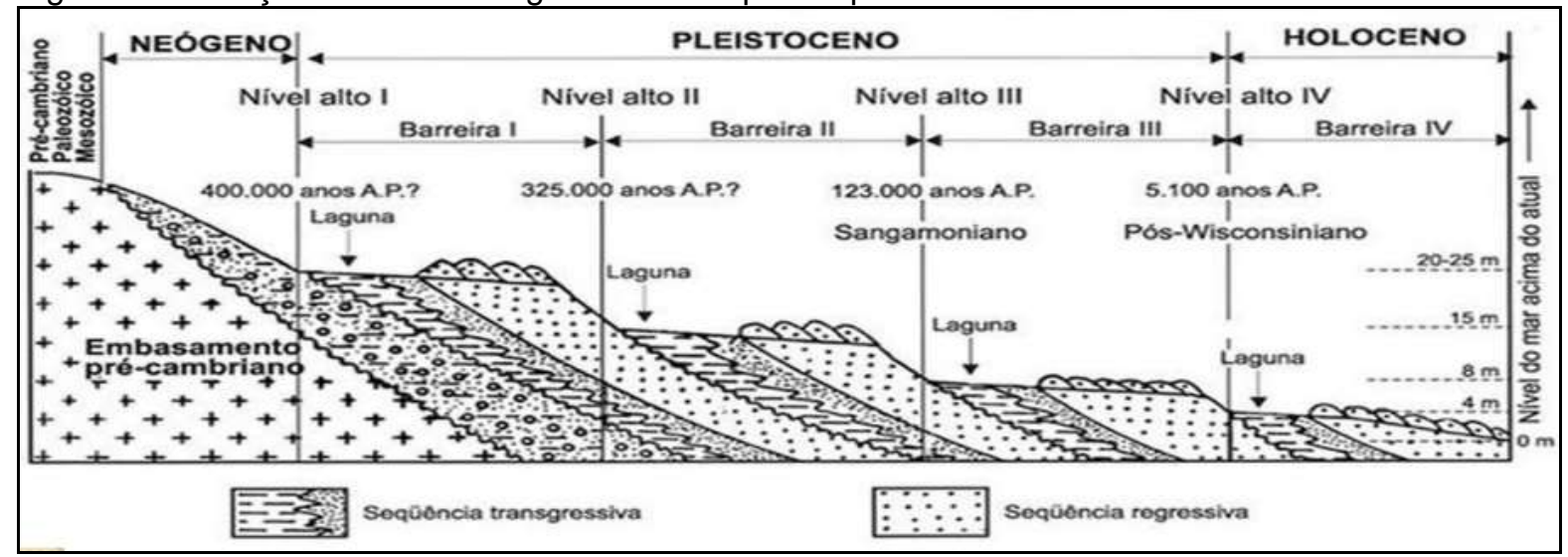

Fonte: Villwock, et al. (1986).

Figura 2: Esquema dos subsistemas pertencentes ao sistema deposicional laguna-barreira.

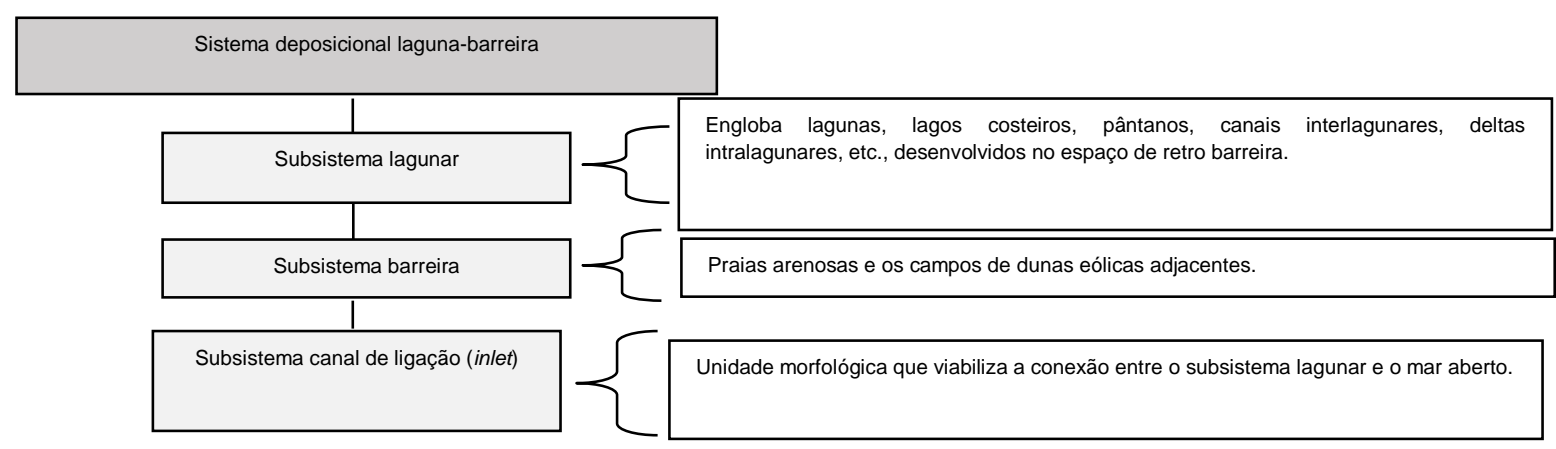


O sistema laguna-barreira IV, representativo da área de estudo, teve seu pico transgressivo há cerca de 5,1 Ka AP (fase isotópica 1), onde o mar alcançou cerca de $4 \mathrm{~m}$ acima do atual.

O sistema barreira é classificado na literatura pelas escolas australiana (ROY et al., 1994; HESP \& SHORT, 1999) e americana (FISHER \& McGOWEN, 1969; BOYD et al., 1992; MORTON, 1994). De acordo com Roy et al. (1994), as barreiras costeiras servem como verdadeiras "barreiras" entre o continente e o oceano, sendo compostas por sedimentos depositados em ambientes praiais, de duna, de canal e delta de maré e como leques de sobrelavagem. Estes sedimentos, que constituem os depósitos alocados na planície costeira, apresentam características granulométricas que são fundamentais para identificação do ambiente de deposição (SUGUIO, 1973).

\section{Área de estudo, materiais e métodos}

A área de estudo compreende uma barreira arenosa holocênica e uma retro barreira constituída em sua maior pelas lagoas Esteves, Faxinal e Mãe Luzia, localizada no setor Sul da província costeira catarinense. O limite geográfico da área de estudo ao norte é a lagoa do Faxinal (coordenadas UTM 669504,65W. e 6809169,01S.), e ao sul a lagoa Mãe Luzia (coordenadas UTM 663399,96W. e $6804057,49 S$.). A leste, o limite geográfico compreende a linha de costa atual e, a oeste, o limite segue entre a retro barreira do sistema deposicional laguna-barreira IV e a barreira do sistema deposicional laguna-barreira III. No entanto, entre as lagoas Esteves e Mãe Luzia a barreira arenosa III adentra em parte à área de estudo (Figura 3). 
Figura 3: Localização da área de estudo.

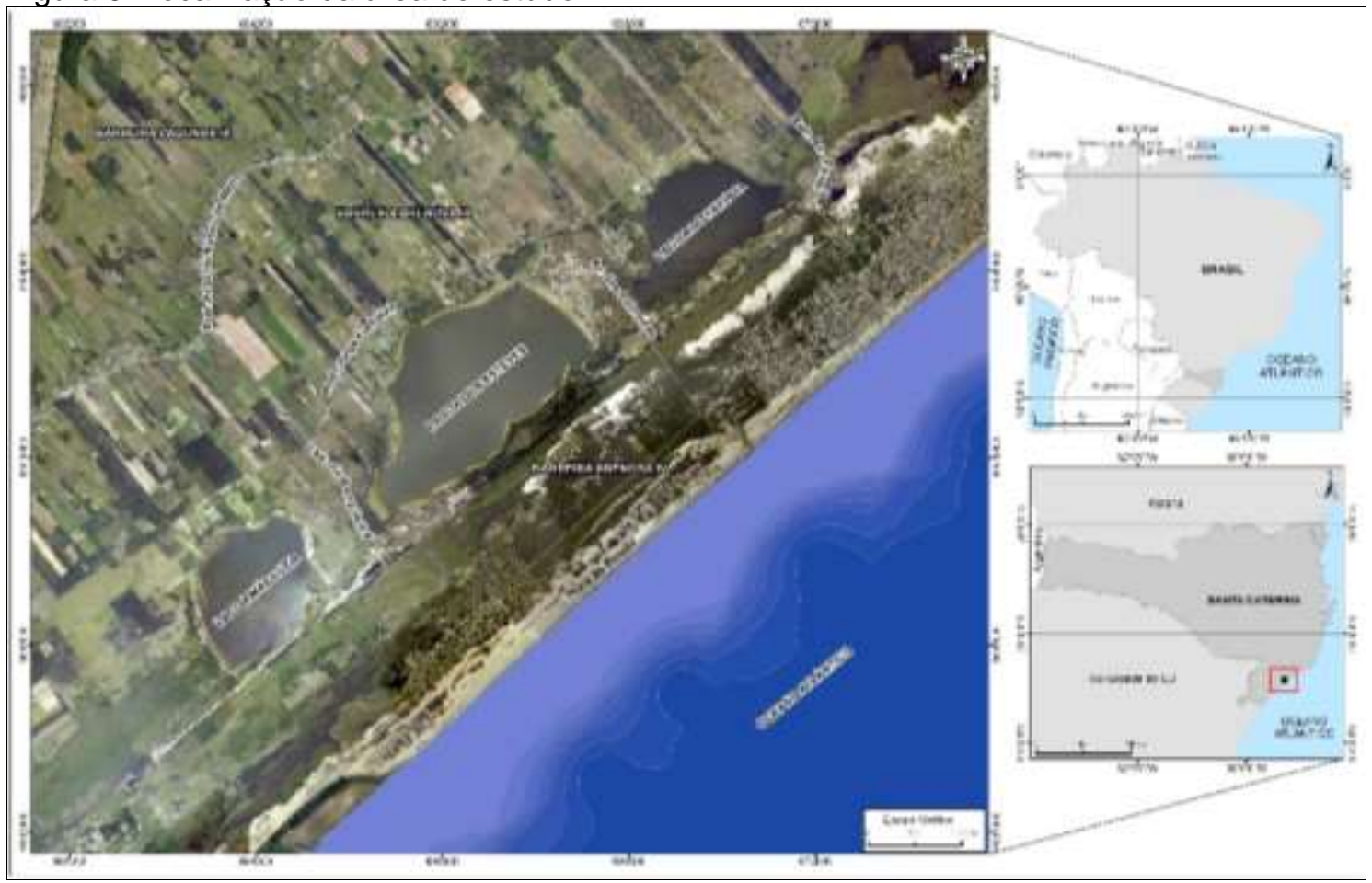

\section{Materiais e métodos}

A metodologia aplicada neste trabalho consistiu em quatro etapas: (1) levantamento bibliográfico e cartográfico; (2) trabalhos de campo; (3) análises laboratoriais; e (4) atividades finais de gabinete.

As bibliografias levantadas de maior relevância são oriundas de trabalhos geológicos realizados na planície costeira do setor Norte do estado do Rio Grande do Sul, isto, pois, a planície costeira da área de estudo assemelha-se muito à planície costeira supracitada.

Durante o levantamento cartográfico, foram obtidas ortofotos digitais do levantamento fotogramétrico do estado de Santa Catarina, com resolução de $0,39 \mathrm{~m}$, escala de uso de 1:5.000, escala máxima de visualização de 1:1.000 e referência altimétrica EGM2008 com 32cm de precisão geoidal. Estas ortofotos, cedidas pela Secretaria do Desenvolvimento Econômico Sustentável de Santa Catarina (SDS/SC), serviram de base para todos os mapeamentos realizados nesta pesquisa. No Quadro 1, segue a lista de ortofotos obtidas com suas concernentes informações. 
Quadro 1: Dados das ortofotos do levantamento fotogramétrico do estado de Santa Catarina utilizadas como base cartográfica para esta pesquisa.

\begin{tabular}{|c|c|c|c|}
\hline DESDOBRAMENTO & $\begin{array}{l}\text { REFERÊNCIA } \\
\text { ESPACIAL }\end{array}$ & DATA & FONTE \\
\hline $\begin{array}{l}\text { Orto - RGB - SH - 22X - B IV - } 3 \text { - NE - C } \\
\text { Orto - RGB - SH - 22X - B IV - } 3 \text { - NE - D } \\
\text { Orto - RGB - SH - 22X - B IV - } 3 \text { - NE - E } \\
\text { Orto - RGB - SH - 22X - B IV - } 3 \text { - NE - F } \\
\text { Orto - RGB - SH - 22X - B IV - } 3 \text { - SE - A } \\
\text { Orto - RGB - SH - 22X - B IV - } 3 \text { - SE - B }\end{array}$ & $\begin{array}{c}\text { Sistema de Referência } \\
\text { Geocêntrico para as } \\
\text { Américas (SIRGAS } \\
\text { 2000) }\end{array}$ & $\begin{array}{l}\text { Abril/2010 a } \\
\text { maio/2013 }\end{array}$ & $\begin{array}{l}\text { SDS/DRHI } \\
\text { Coordenaçã } \\
\text { o de } \\
\text { Cartografia } \\
\text { (CC) }\end{array}$ \\
\hline
\end{tabular}

Após a obtenção das bases cartográficas, visando os trabalhos de geoprocessamento e fotointerpretação, as ortofotos foram organizadas em ambiente SIG (Sistema de Informações Geográficas), com o uso do software ESRI ArcGis 10.3.1. As bases cartográficas foram referenciadas à projeção Universal Transversa de Mercator (UTM) e associadas ao datum vertical de Imbituba/SC e ao datum horizontal SIRGAS 2000, tendo como meridiano central 51W. e fuso 22 sul. As imagens do satélite GeoEye datadas de 2002-2015 disponibilizadas pela plataforma Google através do SIG Google Earth Pro, foram utilizadas como auxílio à análise fotointerpretativa.

Tendo em vista o relacionamento das feições geomorfológicas com as unidades deposicionais, de forma que os limites dos depósitos sedimentares no desenho cartográfico são delineados com o apoio das formas de relevo, a caracterização das feições geomorfológicas torna-se elemento necessário. Dessa forma, foram obtidos Modelos Digitais de Terreno (MDT's), e com a extração de curvas de nível e geração da Triangular Irregular Network (TIN), foi possível representar o modelado da superfície terrestre e melhor interpretar as características geomorfológicas que constituem a área de estudo.

Os MDT's foram cedidos pela Secretaria do Desenvolvimento Econômico Sustentável de Santa Catarina (SDS), com os mesmos desdobramentos e referência espacial das ortofotos digitais. Os outros elementos, como as curvas de nível e a malha triangular, foram gerados através do software ArcGis 10.3.1.

$\mathrm{Na}$ etapa de trabalho de campo foram visitados 27 pontos de coleta considerando os depósitos sedimentares previamente identificados, a partir da abertura de uma trincheira, com aproximadamente $30 \mathrm{~cm}$ de largura e $50 \mathrm{~cm}$ de profundidade (Figura 4). 
Figura 4: Abertura de trincheira e corte em seção colunar para coleta de sedimentos na planície costeira da área de estudo, respectivamente.

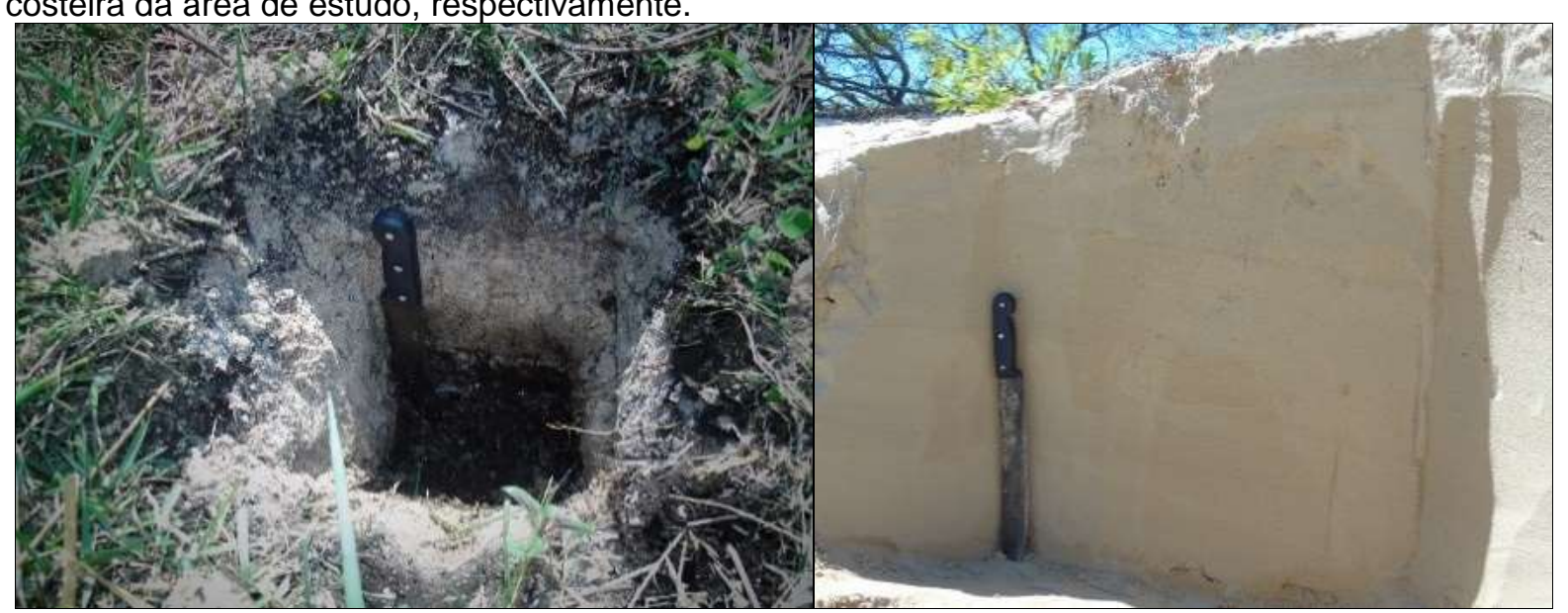

Fonte: Aline Pires Mateus, Janeiro de 2016.

As amostras coletadas no mapeamento geológico foram encaminhadas aos laboratórios do Departamento de Geociências da Universidade Federal de Santa Catarina, com destaque ao Laboratório de Sedimentologia (LABSED), Laboratório de Oceanografia Costeira (LOC) e Laboratório de Geodinâmica Superficial (LAGES). Nesses laboratórios foram realizadas a análise granulométrica, bem como análise quantitativa da matéria orgânica presente nos sedimentos, adotando as metodologias tradicionais desenvolvidas em Suguio (1973) e Toldo Jr. (1997).

\section{Resultados e discussão}

A estratigrafia da área de estudo apresenta cinco unidades geológicas (unidades deposicionais), sendo uma unidade do Quaternário indiferenciado (Depósito fluvial) e quatro unidades do Holoceno (Depósito lagunar, Depósito eólico, Depósito marinho praial e Depósito lagunar praial). Com exceção do Depósito fluvial, aqui definida como pertencente ao sistema deposicional continental, as demais estão inseridas no sistema deposicional transicional ou litorâneo. Estas unidades estão representadas cartograficamente no mapa geológico-geomorfológico da região das lagoas Esteves, Faxinal e Mãe Luzia (Figura 5).

\section{Depósito fluvial}

O Depósito fluvial (Figura 6) caracteriza-se pela deposição de sedimentos transportados pelos cursos fluviais, sendo depositados nas margens destes cursos, 
nas planícies de inundação (áreas de transbordo) e em meandros abandonados. São depósitos formados em ambientes de média à alta energia.

Figura 6: (A) Detalhe do Depósito fluvial nas proximidades das lagoas Faxinal e Esteves; (B) Vista geral do Depósito fluvial na direção SW.

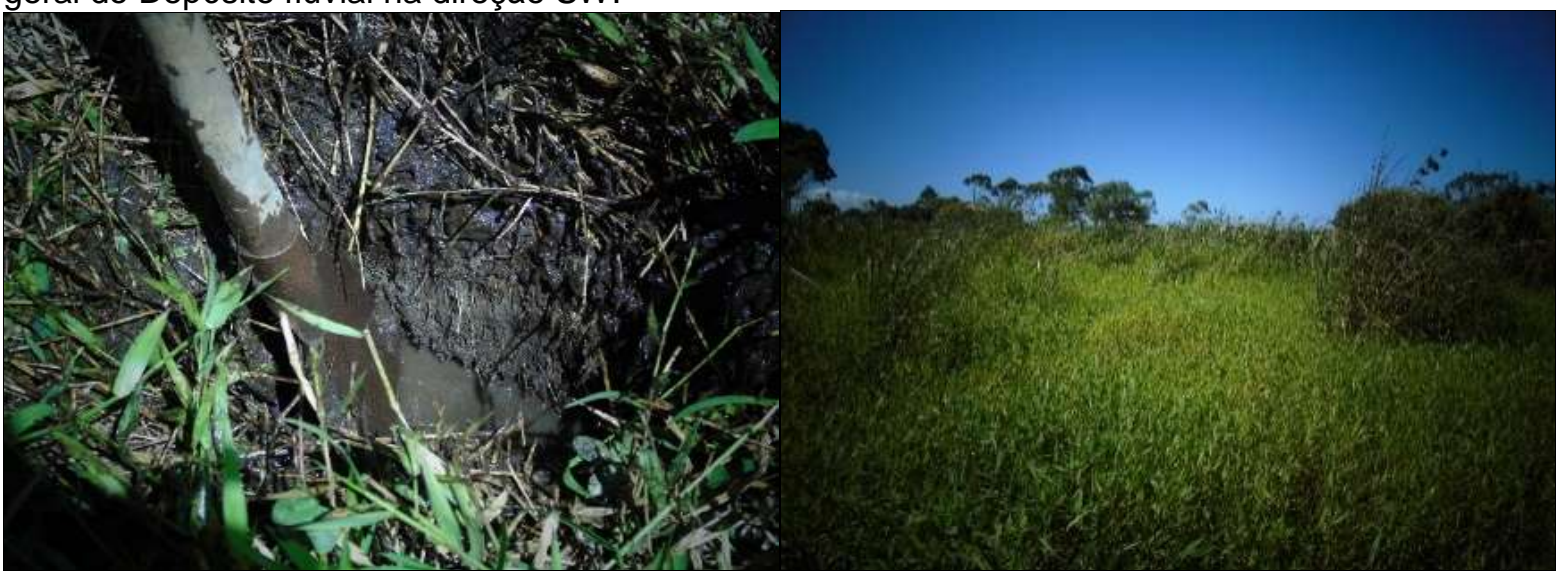

Fonte: Aline Pires Mateus, Janeiro de 2016.

$\mathrm{Na}$ área de estudo o Depósito fluvial está localizado entre depósitos eólicos e marinho praiais, a cerca de $1.400 \mathrm{~m}$ da linha de costa atual, e entre depósitos lagunares e marinho praiais nas imediações da lagoa Mãe Luzia.

Figura 5: Mapa geológico da área de estudo.

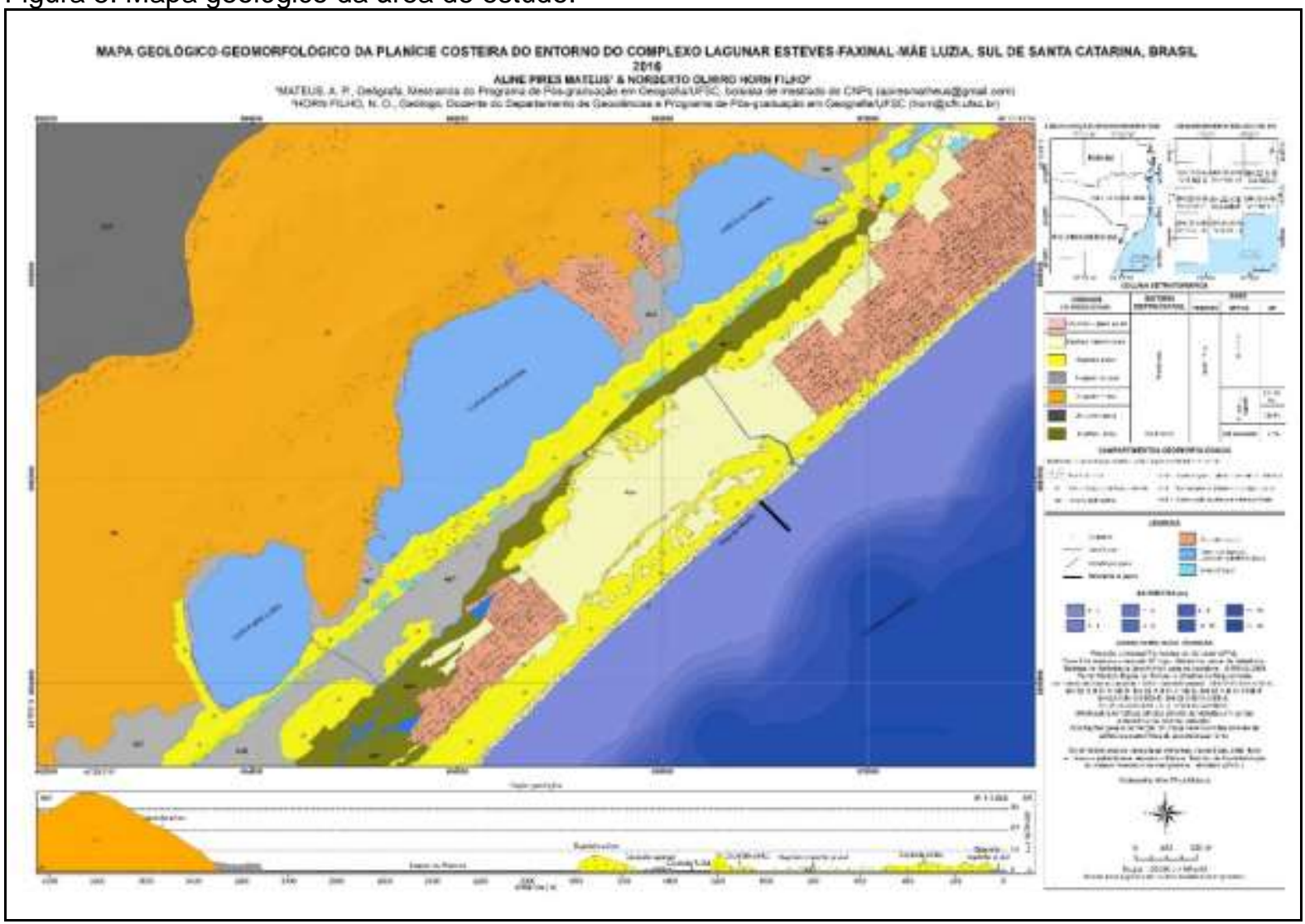


Acredita-se que, possivelmente, pelas características geológicas e geomorfológicas a área em que se situa este depósito seja um antigo canal fluvial abandonado do rio Araranguá.

A amostra F5, representante do Depósito fluvial, consiste de $80,21 \%$ de areia e $19,79 \%$ de silte. A areia constitui-se de $23,12 \%$ de areia fina; $19,12 \%$ de areia média; $16,90 \%$ de areia muita fina; $16,50 \%$ de areia grossa e $4,57 \%$ de areia muito grossa. Na classe silte, predomina o silte grosso $(10,16 \%)$, seguido do silte médio $(5,79 \%)$, silte fino $(2,78 \%)$ e silte muito fino $(1,06 \%)$. O conteúdo de matéria orgânica desta amostra é de $75,02 \%$.

A partir da construção do histograma de distribuição (Figura 7) e considerando os valores de tendência central e dispersão (Quadro 2), observa-se que a amostra F5 constitui-se de sedimentos pobremente selecionados, apresentando curva mesocúrtica, granulometria média areia fina e, assimetria positiva com aporte para sedimentos finos. De acordo com os parâmetros de Folk \& Ward (1957), a amostra F5 foi classificada como areno-siltosa.

Figura 7: Histograma de frequência de distribuição das classes granulométricas da amostra F5.

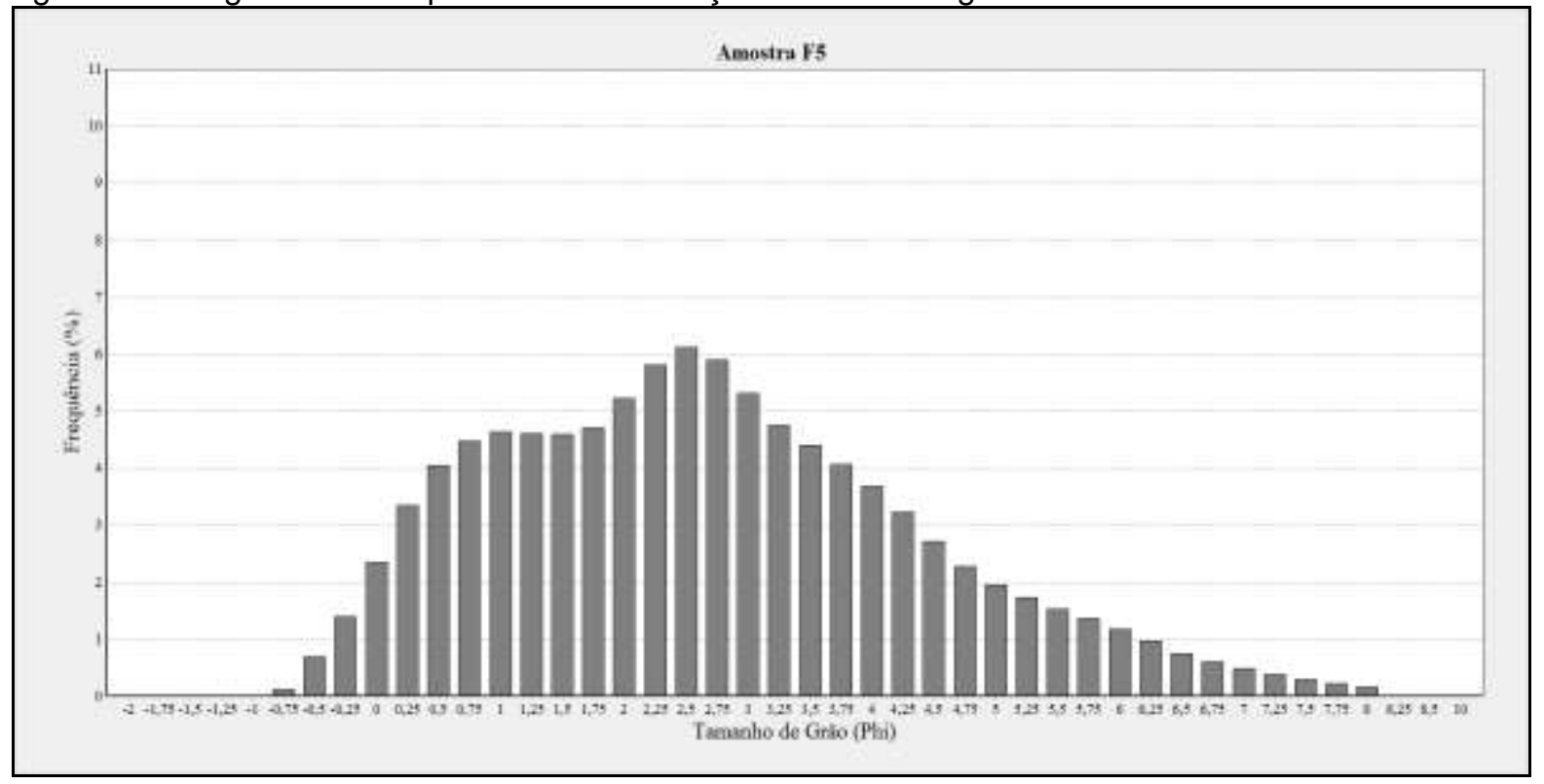

Quadro 2: Medidas de tendência central e dispersão da amostra F5.

\begin{tabular}{|c|c|c|c|c|c|}
\hline Amostra & Média & Mediana & Desvio padrão & Assimetria & Curtose \\
\cline { 2 - 6 } F5 & $2,48 \varnothing$ & $2,41 \varnothing$ & $1,76 \varnothing$ & 0,11 & 0,95 \\
\hline
\end{tabular}

\section{Depósito lagunar}

O Depósito lagunar é formado em ambientes de baixa energia favorecendo o acúmulo de sedimentos finos e, está relacionado ao máximo transgressivo 
holocênico que originou as lagoas costeiras Esteves, Faxinal e Mãe Luzia, que posteriormente com a descida do nível do mar e colmatação destes corpos lagunares, formaram os atuais depósitos lagunares na forma de planícies e terraços (Figura 8).

Figura 8: (A) Detalhe do Depósito lagunar na forma de terraço lagunar. Foi registrada a presença de matéria orgânica característica deste tipo de depósito; (B) Depósito lagunar em canal de ligação entre as lagoas Mãe Luzia e dos Esteves.

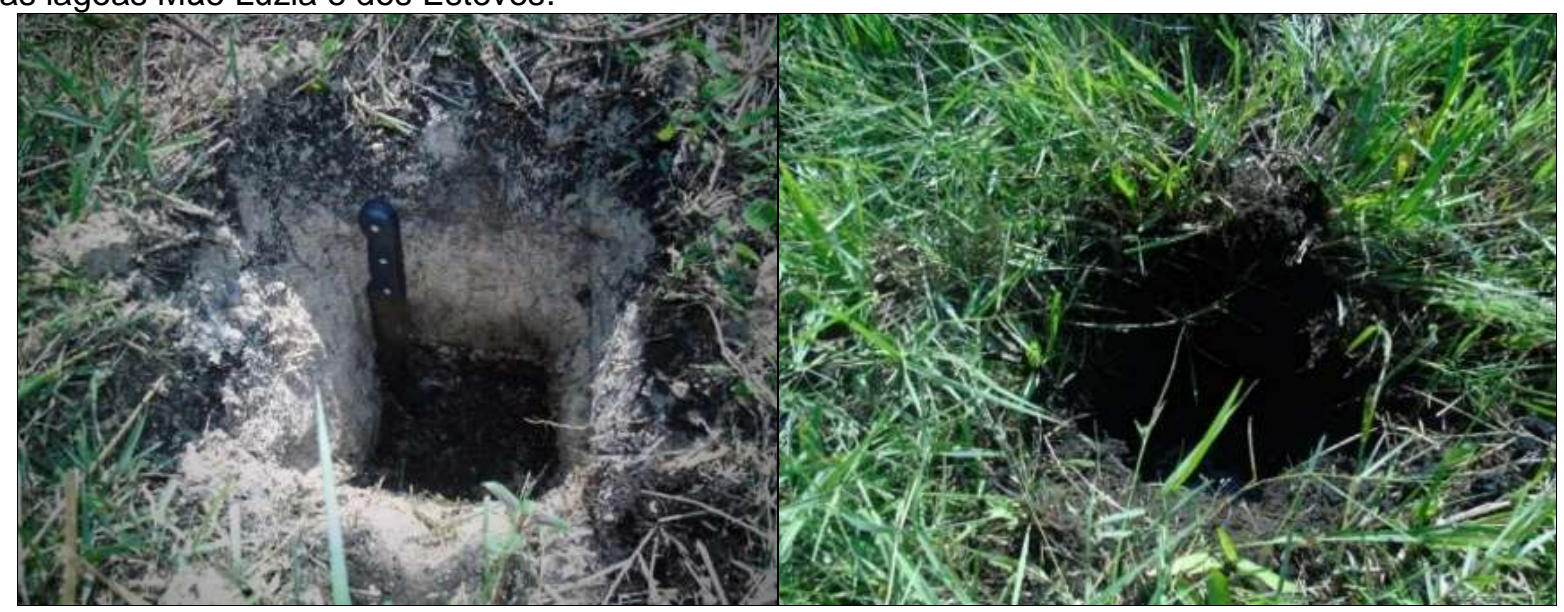

Fonte: Aline Pires Mateus, Janeiro de 2016.

As amostras C1 e C2 representam os depósitos lagunares localizados entre as lagoas Mãe Luzia e Esteves e entre as lagoas Faxinal e Esteves, respectivamente. A amostra ML4 está situada nas proximidades da lagoa Mãe Luzia entre os depósitos eólicos, a amostra ML7 ao sul da lagoa Mãe Luzia e a amostra ML7 na porção oeste da lagoa dos Esteves.

Em relação as características texturais e composicionais, a amostra C1 apresenta $95,6 \%$ de areia e $4,4 \%$ de silte. Na classe areia, a predominância é de areia fina $(64,92 \%)$; seguido de areia média $(19,42 \%)$, areia muito fina $(9,97 \%)$ e areia grossa (1,29\%). Na classe silte a amostra apresentou 1,44\% de silte grosso; $1,35 \%$ de silte médio; $0,99 \%$ de silte fino; e $0,62 \%$ de silte muito fino. O conteúdo de matéria orgânica da amostra C1 é de 30,78\%.

O histograma de distribuição (Figura 9) e os valores de tendência central e dispersão (Quadro 3), mostram que a amostra C1 apresenta sedimentos moderadamente selecionados, com curva leptocúrtica, granulometria média areia fina e, assimetria aproximadamente simétrica com tendência para aporte de sedimentos finos. Esta amostra classifica-se como areno-siltosa.

Figura 9: Histograma de frequência de distribuição das classes granulométricas da amostra C1. 


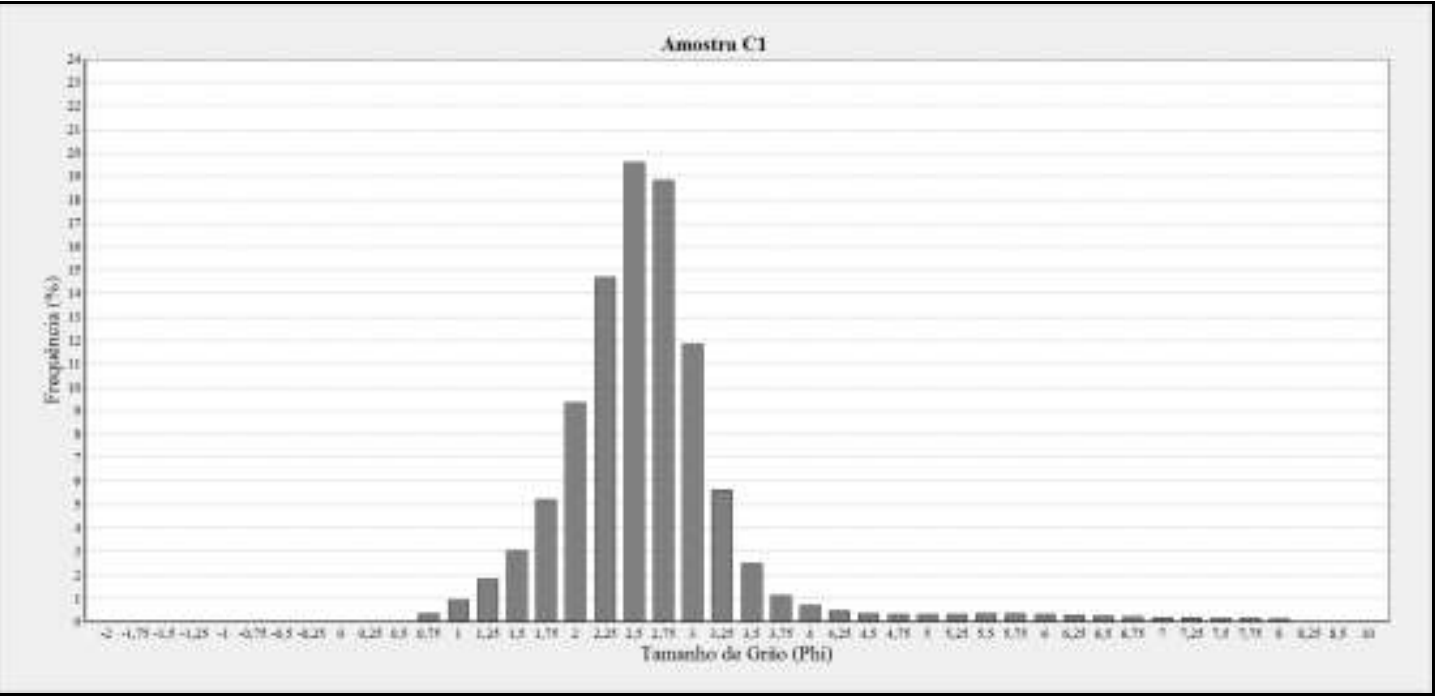

Quadro 3: Medidas de tendência central e dispersão da amostra C1.

\begin{tabular}{|c|c|c|c|c|c|}
\hline \multirow{2}{*}{$\begin{array}{c}\text { Amostra } \\
\text { C1 }\end{array}$} & Média & Mediana & Seleção & Assimetria & Curtose \\
\cline { 2 - 6 } & $2,42 \varnothing$ & $2,43 \varnothing$ & $0,63 \varnothing$ & 0,05 & 1,38 \\
\hline
\end{tabular}

A amostra C2 constitui-se de $44,83 \%$ de areia fina; $44,34 \%$ de areia média; $7,42 \%$ de areia grossa, $3,36 \%$ de areia muito fina, e $0,05 \%$ de areia muito grossa. 0 conteúdo de matéria orgânica da amostra C2 é de 0,12\%. Esta amostra apresenta sedimentos moderadamente selecionados, exibindo curva mesocúrtica, granulometria média areia média, assimetria aproximadamente simétrica com tendência para aporte de sedimentos mais grosseiros e, classificada como arenosa. A Figura 10 apresenta o histograma de distribuição de frequência e o Quadro 4 os valores de tendência central e dispersão.

Figura 10: Histograma de frequência de distribuição das classes granulométricas da amostra C2.

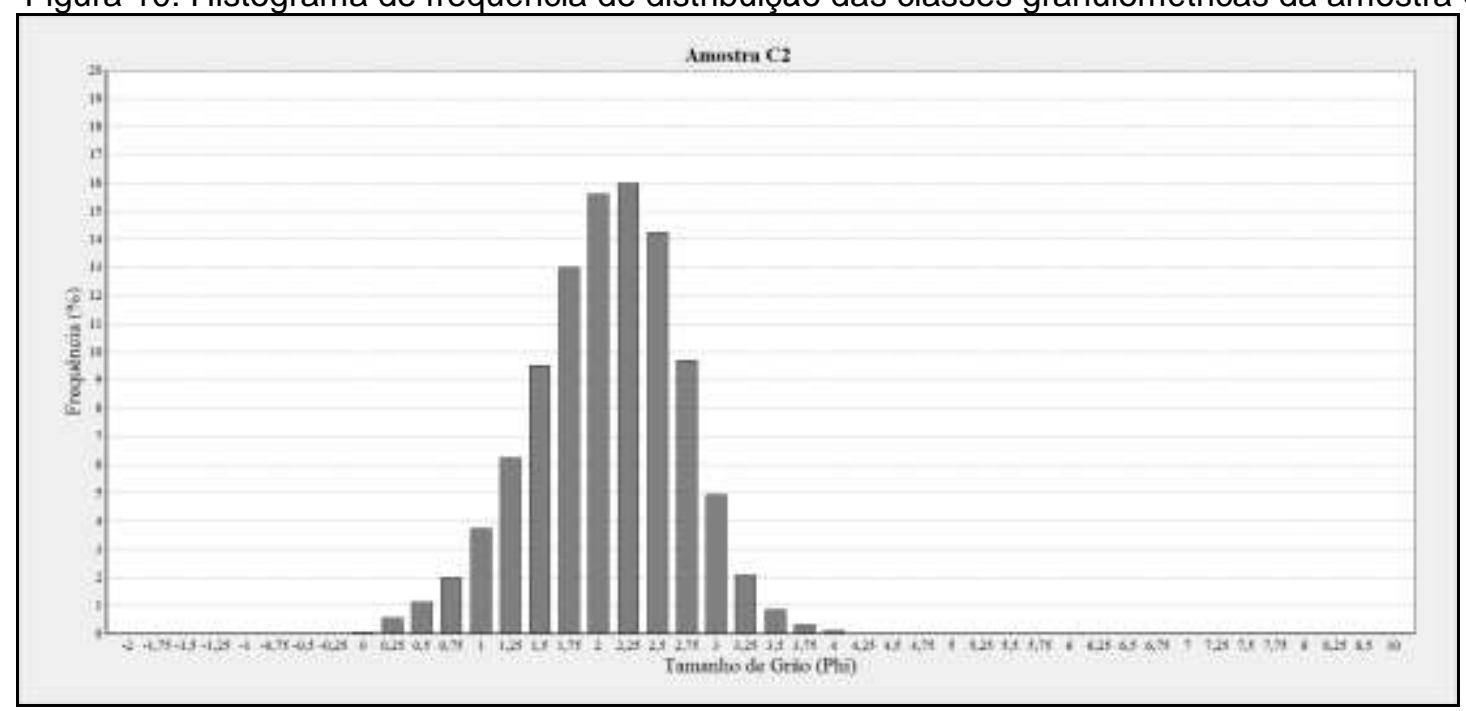

Quadro 4: Medidas de tendência central e dispersão da amostra C2. 


\begin{tabular}{|c|c|c|c|c|c|}
\hline \multirow{2}{*}{$\begin{array}{c}\text { Amostra } \\
\text { C2 }\end{array}$} & Média & Mediana & Seleção & Assimetria & Curtose \\
\cline { 2 - 6 } & $1,94 \varnothing$ & $1,97 \varnothing$ & $0,62 \varnothing$ & $-0,07$ & 1,01 \\
\hline
\end{tabular}

A amostra ML4 apresenta 89,1\% de areia e 13,9\% de silte. Da classe areia, predomina areia fina (42,53\%), seguido de areia média (23,28\%), areia muito fina $(16,64 \%)$ e areia grossa (3,65\%). Da classe silte, predomina o silte grosso $(6,68 \%)$, seguido do silte médio $(4,66 \%)$, silte fino $(2,10 \%)$ e silte muito fino $(0,46 \%)$. 0 conteúdo de matéria orgânica da amostra ML4 é de 92,96\%. O histograma de distribuição (Figura 11) e os valores de tendência central e dispersão (Quadro 5), mostram que a amostra ML4 apresenta sedimentos pobremente selecionados, com curva leptocúrtica, granulometria média areia fina e, assimetria positiva com tendência para aporte de sedimentos finos. Esta amostra classifica-se como arenosiltosa.

Figura 11: Histograma de frequência de distribuição das classes granulométricas da amostra ML4.

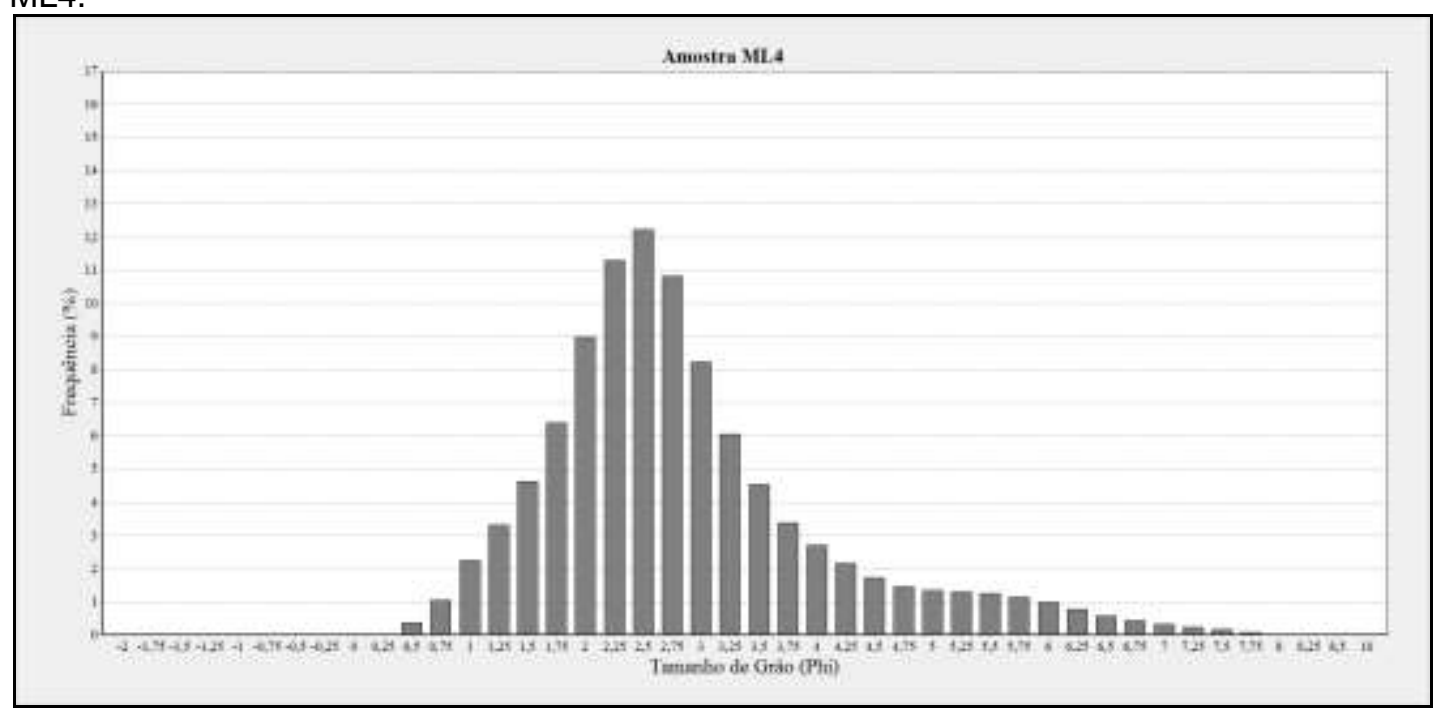

Quadro 5: Medidas de tendência central e dispersão da amostra ML4.

\begin{tabular}{|c|c|c|c|c|c|}
\hline \multirow{2}{*}{$\begin{array}{c}\text { Amostra } \\
\text { ML4 }\end{array}$} & Média & Mediana & Seleção & Assimetria & Curtose \\
\cline { 2 - 6 } & $2,65 \varnothing$ & $2,49 \varnothing$ & $1,19 \varnothing$ & 0,29 & 1,38 \\
\hline
\end{tabular}

A amostra ML7 possui $91,26 \%$ de areia e 8,74\% de silte. Da classe areia, predomina areia fina $(58,19 \%)$, seguido de areia média $(22,96 \%)$, areia muito fina $(8,99 \%)$ e areia grossa (1,12\%). Da classe silte, predomina o silte médio $(3,48 \%)$, seguido do silte grosso $(2,39 \%)$, silte fino $(2,05 \%)$ e silte muito fino $(0,82 \%)$. Possui $37,92 \%$ de conteúdo orgânico. Esta amostra apresenta sedimentos moderadamente selecionados, com curva muito leptocúrtica, granulometria média areia fina, 
assimetria muito positiva com aporte para sedimentos finos e classificada como areno-siltosa. A Figura 12 apresenta o histograma de distribuição de frequência e o Quadro 6, os valores de tendência central e dispersão.

Figura 12: Histograma de frequência de distribuição das classes granulométricas da amostra ML7.

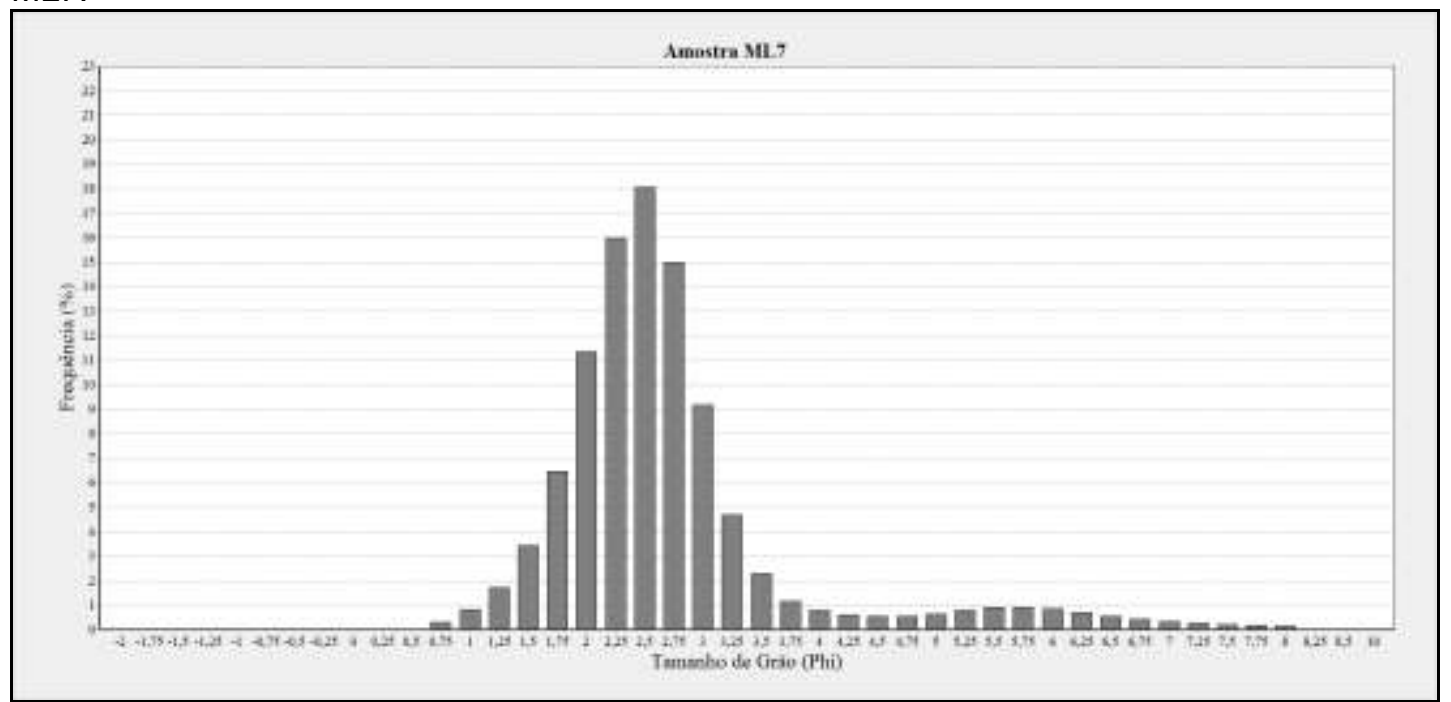

Quadro 6: Medidas de tendência central e dispersão da amostra ML7.

\begin{tabular}{|c|c|c|c|c|c|}
\hline $\begin{array}{c}\text { Amostra } \\
\text { ML7 }\end{array}$ & Média & Mediana & Seleção & Assimetria & Curtose \\
\cline { 2 - 6 } & $2,43 \varnothing$ & $2,38 \varnothing$ & $0,92 \varnothing$ & 0,30 & 2,07 \\
\hline
\end{tabular}

A amostra LE7 apresenta $88,52 \%$ de areia e $11,48 \%$ de silte. Da classe areia, predomina areia média $(40,09 \%)$, seguido de areia grossa $(36,26 \%)$, areia fina $(8,12 \%)$ e areia muito grossa $(2,57 \%)$. Da classe silte, predomina o silte médio $(3,95 \%)$, seguido do silte fino $(3,32 \%)$, silte grosso $(1,9 \%)$ e silte muito fino $(1,82 \%)$. O conteúdo de argila é de $0,49 \%$, enquanto que o conteúdo de matéria orgânica é de $36,2 \%$. A amostra apresenta sedimentos pobremente selecionados, com curva muito leptocúrtica, granulometria média areia média, assimetria muito positiva e classificada como areno silto-argilosa. A Figura 13 apresenta o histograma de distribuição de frequência e o Quadro 7 os valores de tendência central e dispersão. 
Figura 13: Histograma de frequência de distribuição das classes granulométricas da amostra LE7.

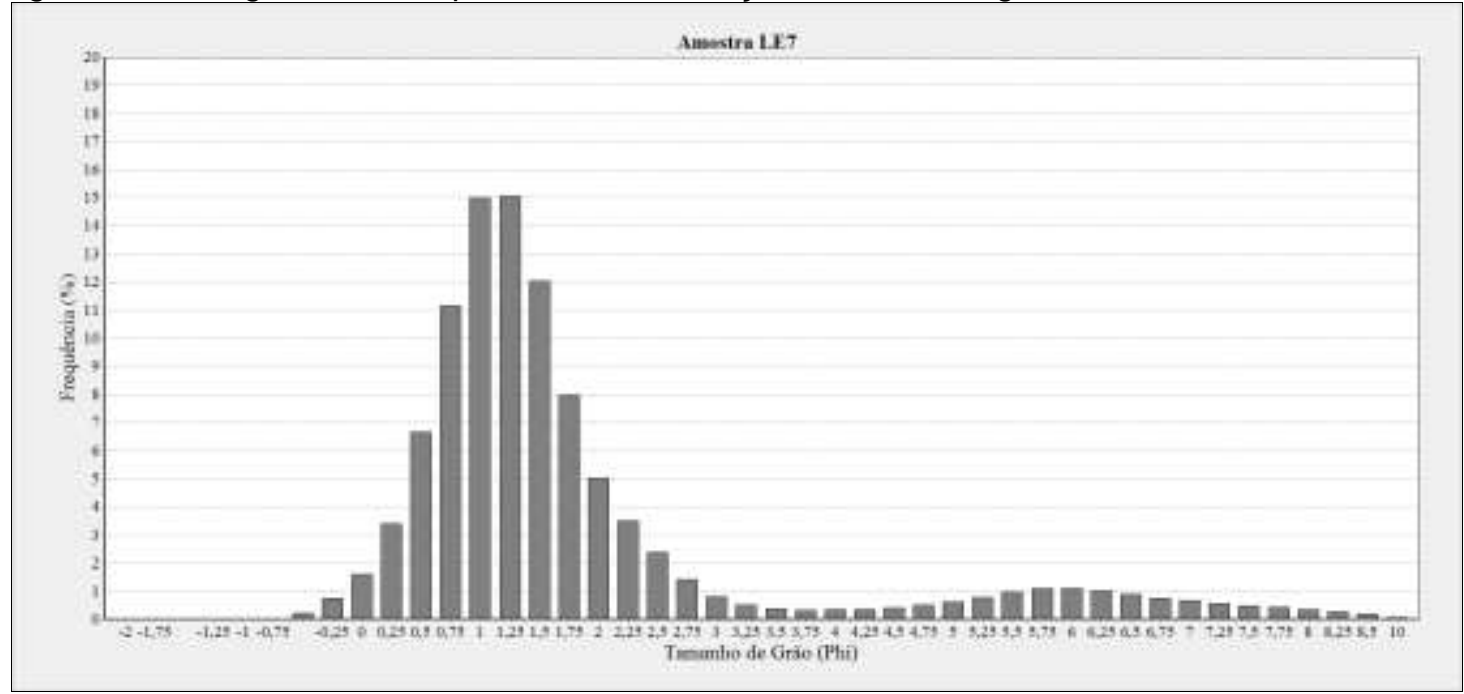

Quadro 7: Medidas de tendência central e dispersão da amostra LE7.

\begin{tabular}{|c|c|c|c|c|c|}
\hline \multirow{2}{*}{$\begin{array}{c}\text { Amostra } \\
\text { LE7 }\end{array}$} & Média & Mediana & Seleção & Assimetria & Curtose \\
\cline { 2 - 6 } & $1,39 \varnothing$ & $1,18 \varnothing$ & $1,36 \varnothing$ & 0,49 & 2,36 \\
\hline
\end{tabular}

O Depósito lagunar da área de estudo exibe predominância de sedimentos moderadamente selecionados com aporte para sedimentos finos. No entanto, a amostra C2, apresenta pequena quantidade de matéria orgânica e aporte para sedimentos mais grosseiros, o que aponta para formação em um ambiente de maior energia.

\section{Depósito eólico}

O Depósito eólico (Figura 14) caracteriza-se pela deposição de sedimentos transportados pela ação eólica, caracterizado por um ambiente de alta energia, sendo representado na área de estudo por dunas móveis, semifixas e fixas. Este depósito é distribuído na área em três setores: setor (1), situa-se paralelamente à linha de costa, distando à cerca de $30 \mathrm{~m}$, separado da mesma pela praia atual; setor (2) entre o Depósito marinho praial na forma de cordões regressivos, distando à cerca de $1.000 \mathrm{~m}$ da linha de costa e 500m da margem leste das lagoas; e, setor (3) situa-se conexo à margem oeste das lagoas com altitude máxima em torno de $16 \mathrm{~m}$. 
Figura 14: (A) Detalhe do Depósito eólico na forma de duna à leste da lagoa do Faxinal. Foi registrada a presença de dunas móveis e semifixas; (B) Dunas paralelas à linha de costa localizadas à leste das lagoas Esteves e Faxinal.

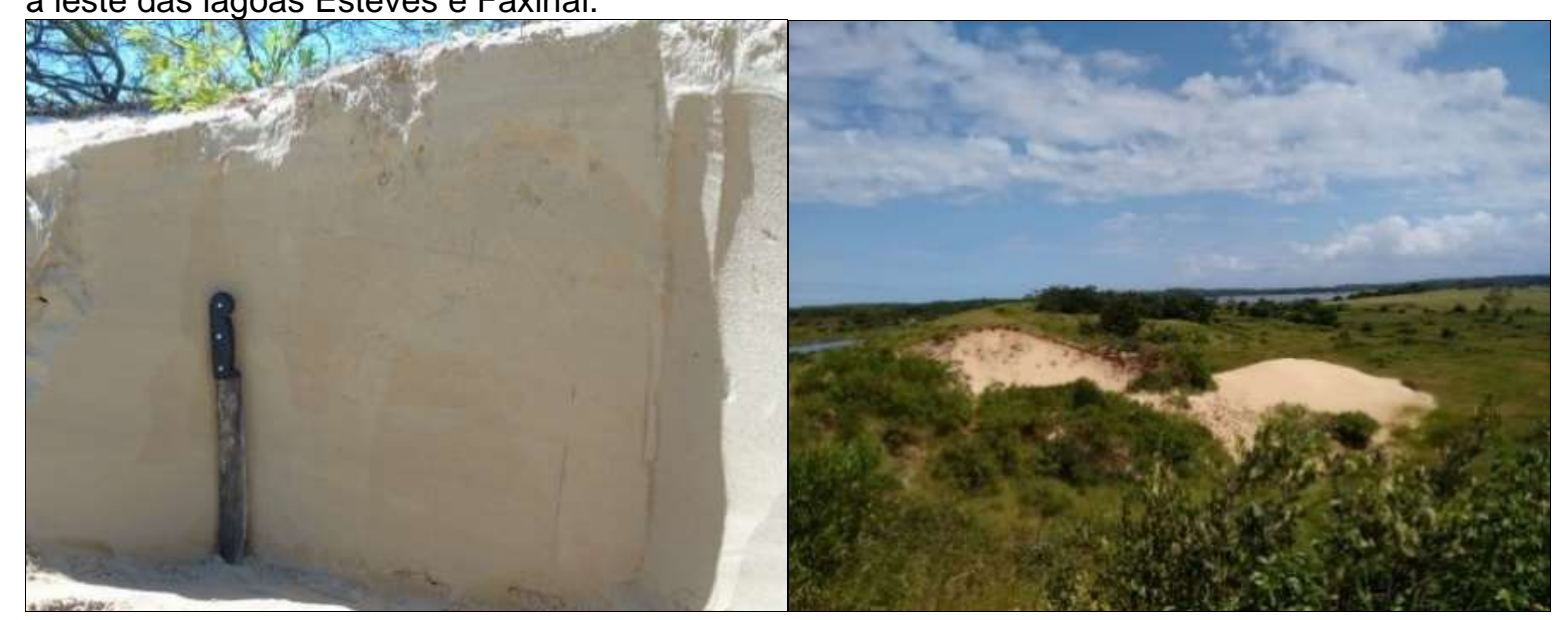

Fonte: Aline Pires Mateus, Janeiro de 2016.

No setor (1) há ausência de vegetação sobre as dunas, caracterizando-as como móveis; no setor (2) as dunas caracterizam-se pela presença e ausência de vegetação, denominadas de dunas semifixas, entretanto, mais ao sul da poligonal de estudo ocorre marcante presença de vegetação caracterizando-as como dunas fixas nesta porção; no setor (3) as dunas apresentam-se em fixas e semifixas.

As características texturais predominantes do Depósito eólico estão expressas nas amostras ML2, LE3, LE5, F2 e F4.

A amostra ML2 consiste de $70,96 \%$ de areia fina; $22,82 \%$ de areia média; $5,57 \%$ de areia muito fina; e $0,65 \%$ de areia grossa. O histograma de distribuição (Figura 15) e os valores de tendência central e dispersão (Quadro 8), mostram que a amostra ML2 apresenta sedimentos bem selecionados, típico do ambiente em que está inserida, com curva mesocúrtica, granulometria média areia fina e, assimetria aproximadamente simétrica. Esta amostra classifica-se como arenosa. 
Figura 15: Histograma de frequência de distribuição das classes granulométricas da amostra ML2.

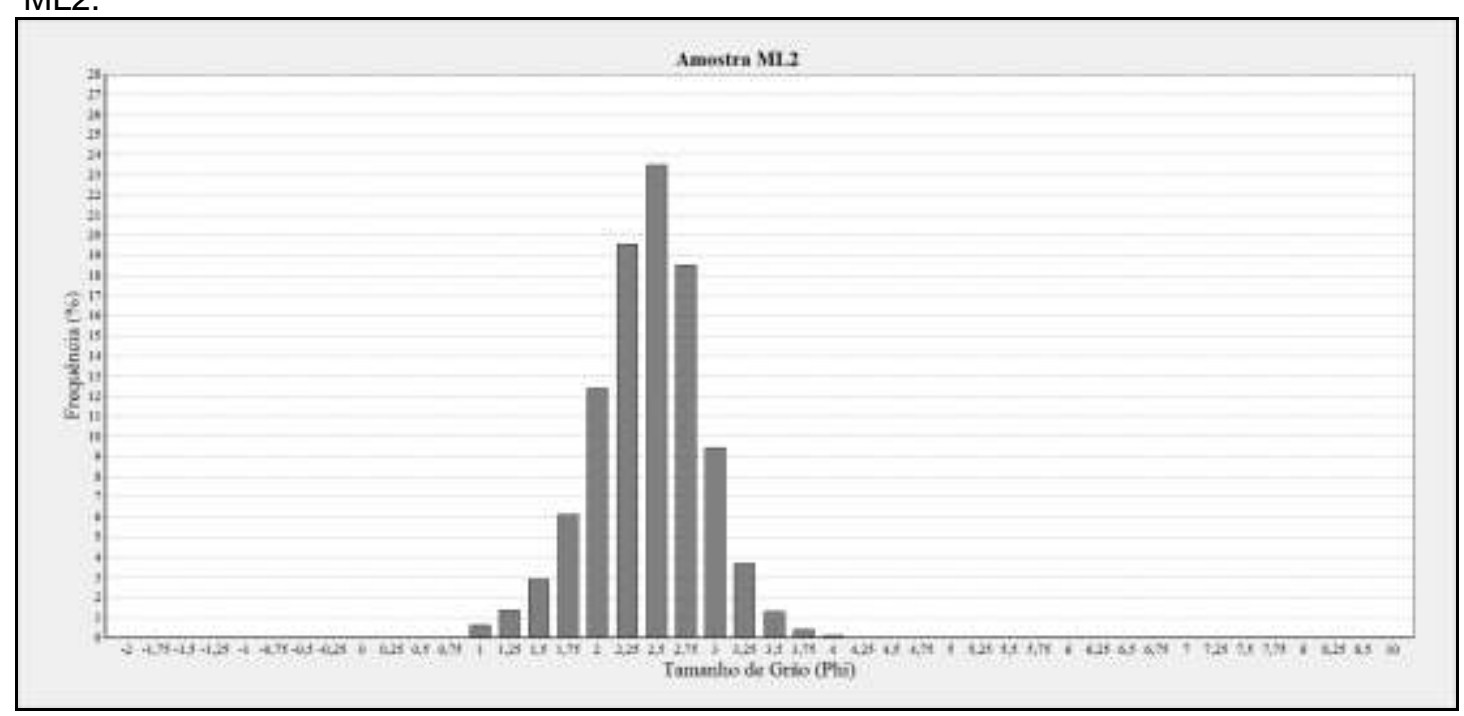

Quadro 8: Medidas de tendência central e dispersão da amostra ML2.

\begin{tabular}{|c|c|c|c|c|c|}
\hline $\begin{array}{c}\text { Amostra } \\
\text { ML2 }\end{array}$ & Média & Mediana & Seleção & Assimetria & Curtose \\
\cline { 2 - 6 } & $2,30 \varnothing$ & $2,32 \varnothing$ & $0,45 \varnothing$ & $-0,07$ & 1,05 \\
\hline
\end{tabular}

A amostra LE3 apresenta 70,6\% de areia fina; $24,82 \%$ de areia média; 3,9\% de areia muito fina; e $0,68 \%$ de areia grossa. Esta amostra apresenta sedimentos bem selecionados, com curva mesocúrtica, granulometria média de areia fina, assimetria aproximadamente simétrica e classificada como arenosa. A Figura 16 apresenta o histograma de distribuição de frequência e o Quadro 9 os valores de tendência central e dispersão.

Figura 16: Histograma de frequência de distribuição das classes granulométricas da amostra LE3.

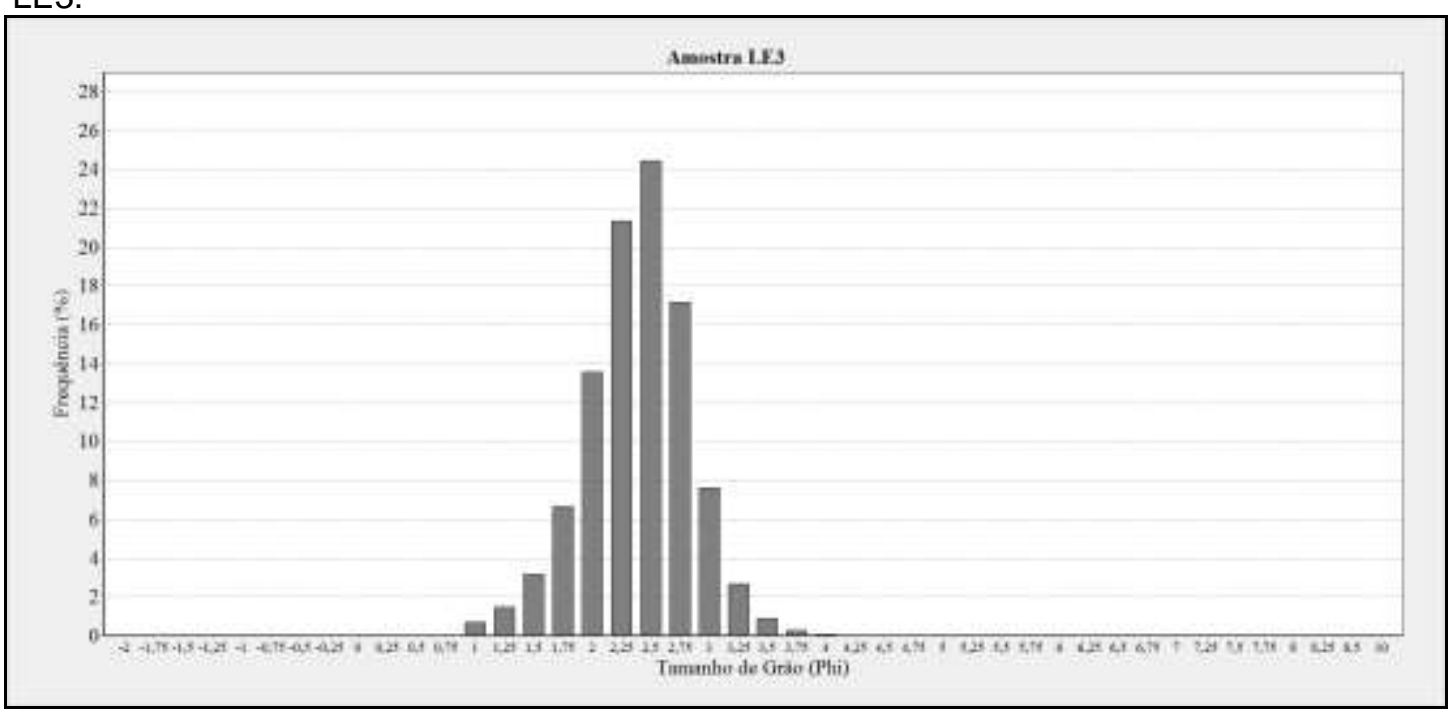


Quadro 9: Medidas de tendência central e dispersão da amostra LE3.

\begin{tabular}{|c|c|c|c|c|c|}
\hline \multirow{2}{*}{$\begin{array}{c}\text { Amostra } \\
\text { LE3 }\end{array}$} & Média & Mediana & Seleção & Assimetria & Curtose \\
\cline { 2 - 6 } & $2,26 \varnothing$ & $2,28 \varnothing$ & $0,44 \varnothing$ & $-0,07$ & 1,08 \\
\hline
\end{tabular}

A amostra LE5 possui $62,67 \%$ de areia fina; $32,77 \%$ de areia média; $3,08 \%$ de areia muita fina; e 1,48\% de areia grossa. O histograma de distribuição (Figura 17) e os valores de tendência central e dispersão (Quadro 10), mostram que a amostra ML2 apresenta sedimentos bem selecionados, curva mesocúrtica, granulometria média areia fina e, assimetria aproximadamente simétrica. Esta amostra classifica-se como arenosa.

Figura 17: Histograma de frequência de distribuição das classes granulométricas da amostra LE5.

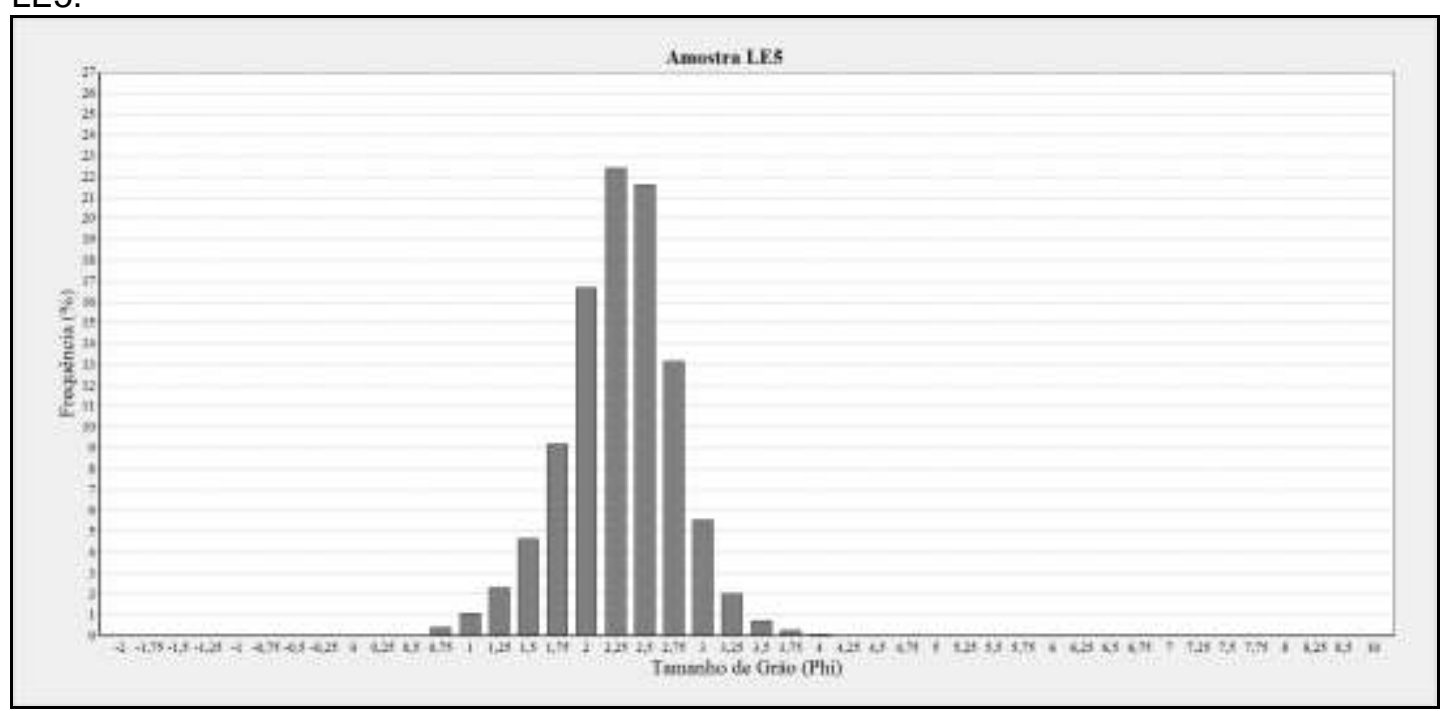

Quadro 10: Medidas de tendência central e dispersão da amostra LE5.

\begin{tabular}{|c|c|c|c|c|c|}
\hline \multirow{2}{*}{$\begin{array}{c}\text { Amostra } \\
\text { LE5 }\end{array}$} & Média & Mediana & Seleção & Assimetria & Curtose \\
\cline { 2 - 6 } & $2,16 \varnothing$ & $2,17 \varnothing$ & $0,46 \varnothing$ & $-0,05$ & 1,08 \\
\hline
\end{tabular}

A amostra F2 apresenta $66,29 \%$ de areia fina; $28,13 \%$ de areia média; $4,40 \%$ de areia muito fina; $1,18 \%$ de areia grossa. Esta amostra apresenta sedimentos bem selecionados, com curva mesocúrtica, granulometria média areia fina, assimetria aproximadamente simétrica e classificada como arenosa. A Figura 18 apresenta o histograma de distribuição de frequência e o Quadro 11 os valores de tendência central e dispersão. 
Figura 18: Histograma de frequência de distribuição das classes granulométricas da amostra F2.

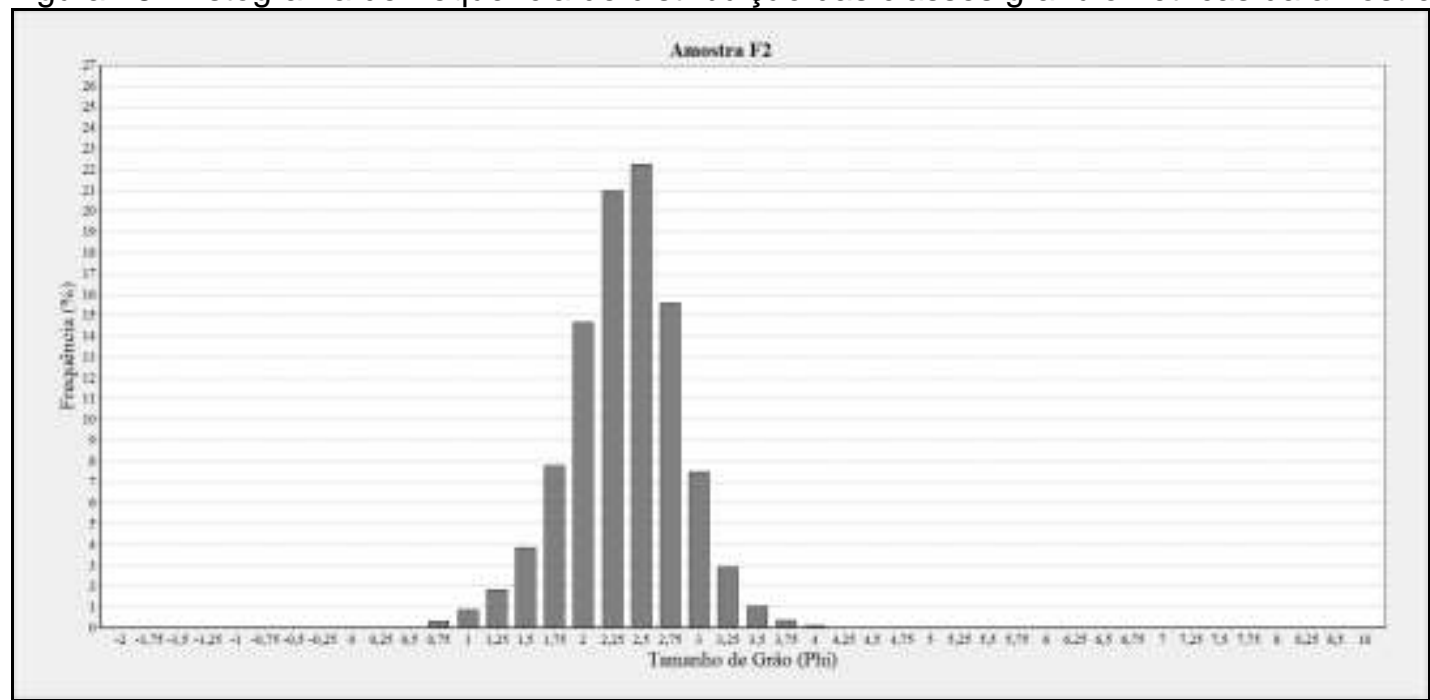

Quadro 11: Medidas de tendência central e dispersão da amostra F2.

\begin{tabular}{|c|c|c|c|c|c|}
\hline \multirow{2}{*}{$\begin{array}{c}\text { Amostra } \\
\text { F2 }\end{array}$} & Média & Mediana & Seleção & Assimetria & Curtose \\
\cline { 2 - 6 } & $2,23 \varnothing$ & $2,24 \varnothing$ & $0,47 \varnothing$ & $-0,06$ & 1,07 \\
\hline
\end{tabular}

A amostra F4 possui 74,99\% de areia fina; $18,6 \%$ de areia média; 5,94\% de areia muito fina; e $0,47 \%$ de areia grossa. A amostra apresenta sedimentos bem selecionados, com curva mesocúrtica, granulometria média areia fina, assimetria aproximadamente simétrica e classificada como arenosa. A Figura 19 apresenta o histograma de distribuição de frequência e o Quadro 12 os valores de tendência central e dispersão.

Figura 19: Histograma de frequência de distribuição das classes granulométricas da amostra F4.

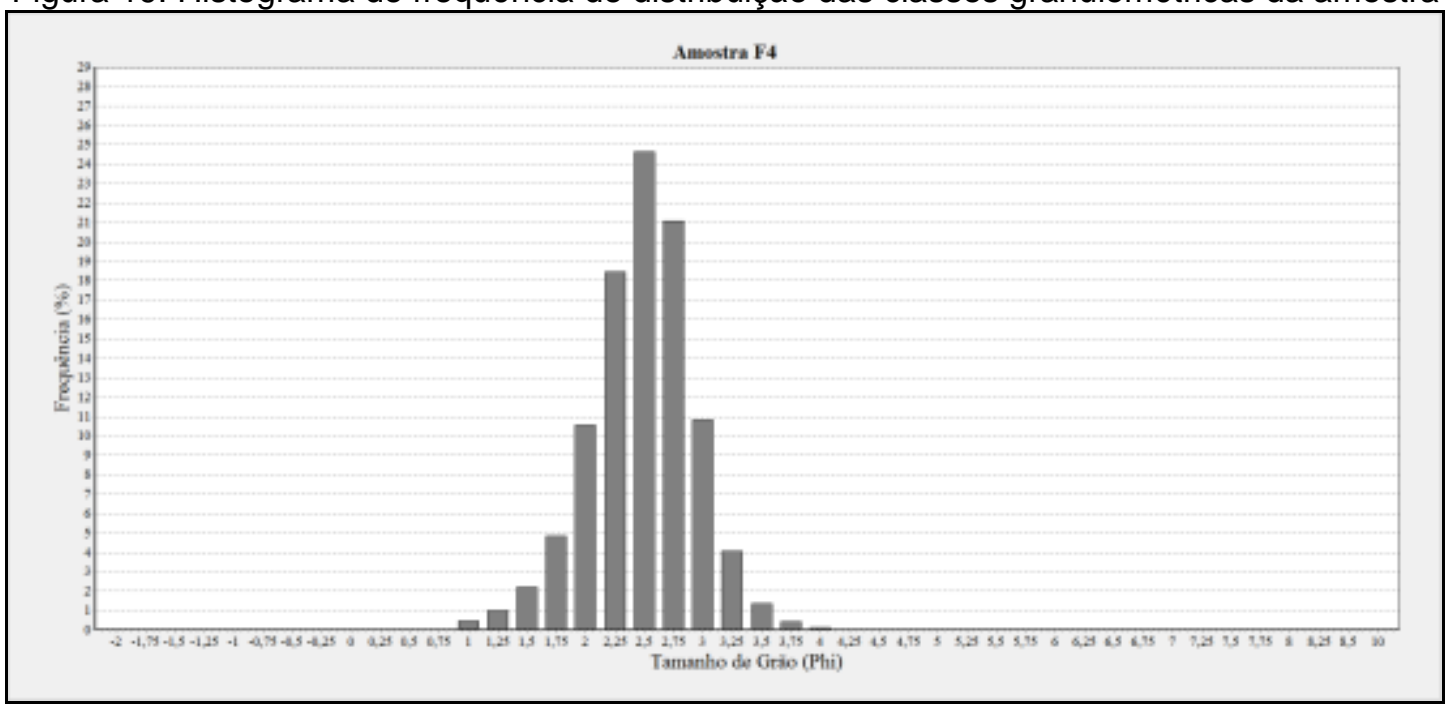


Quadro 12: Medidas de tendência central e dispersão da amostra F4.

\begin{tabular}{|c|c|c|c|c|c|}
\hline \multirow{2}{*}{$\begin{array}{c}\text { Amostra } \\
\text { F4 }\end{array}$} & Média & Mediana & Seleção & Assimetria & Curtose \\
\cline { 2 - 6 } & $2,35 \varnothing$ & $2,37 \varnothing$ & $0,43 \varnothing$ & $-0,07$ & 1,06 \\
\hline
\end{tabular}

\section{Depósito marinho praial}

A unidade deposicional descrita a seguir corresponde ao Depósito marinho praial na forma de praia (Figura 20). Este depósito resulta do transporte de sedimentos marinhos da zona praial para o pós-praia por meio da energia exercida pelas ondas. $\mathrm{Na}$ área de estudo representa a praia atual, com largura em torno de 30m, fazendo limite com o oceano Atlântico e com o Depósito eólico. As características texturais predominantes deste depósito são descritas a partir das amostras coletadas ML1, LE1, LE2 e F1.

A amostra ML1 apresenta predominância de areia fina com 57,63\%; seguida de areia média com $37,82 \% ; 2,78 \%$ de areia muito fina; e 1,77\% de areia grossa. $O$ histograma de distribuição (Figura 21) e os valores de tendência central e dispersão (Quadro 13), mostram que a amostra ML1 apresenta sedimentos bem selecionados, curva mesocúrtica, granulometria média areia fina e, aproximadamente simétrica. Esta amostra classifica-se como arenosa.

Figura 20: (A) Detalhe do Depósito marinho praial, ponto de coleta no pós-praia mostrando sedimentos arenosos finos, bem selecionados, com estratificação plano paralela; (B) Vista para sul do Depósito marinho praial, setor de pós-praia no Balneário Rincão.

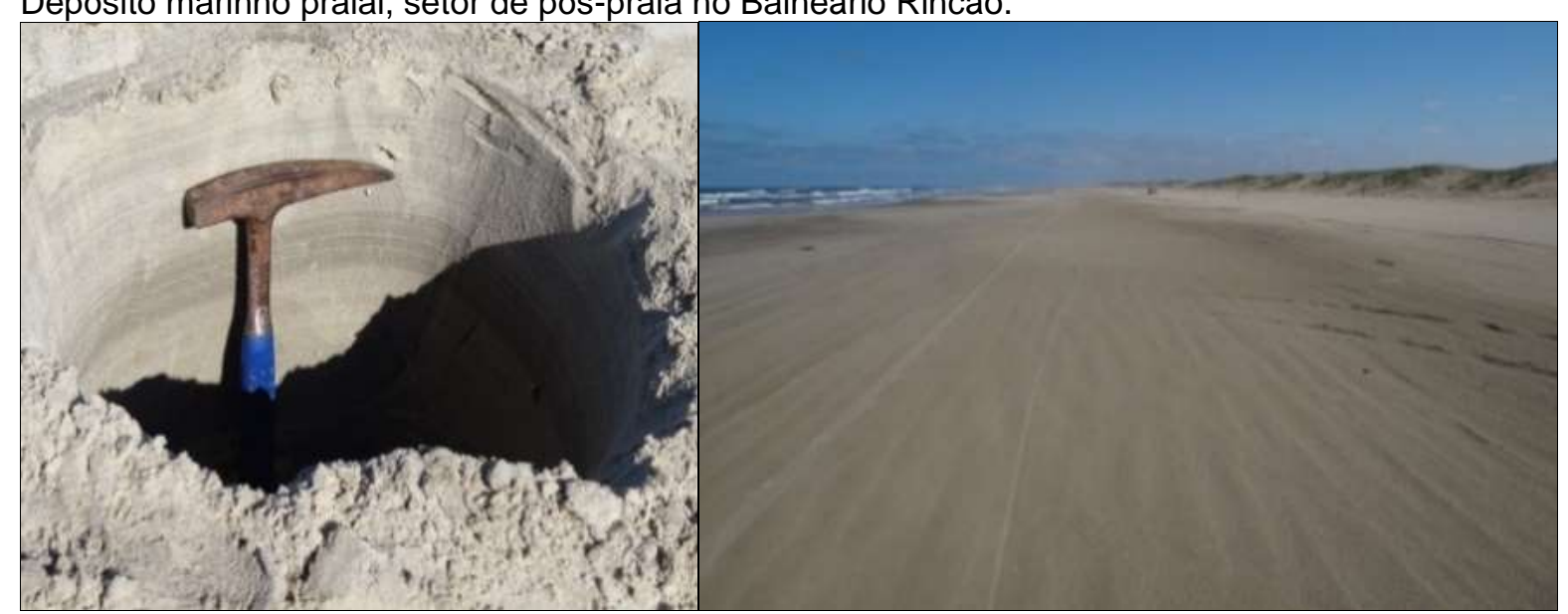

Fonte: Aline Pires Mateus, Janeiro de 2016. 
Figura 21: Histograma de frequência de distribuição das classes granulométricas da amostra ML1.

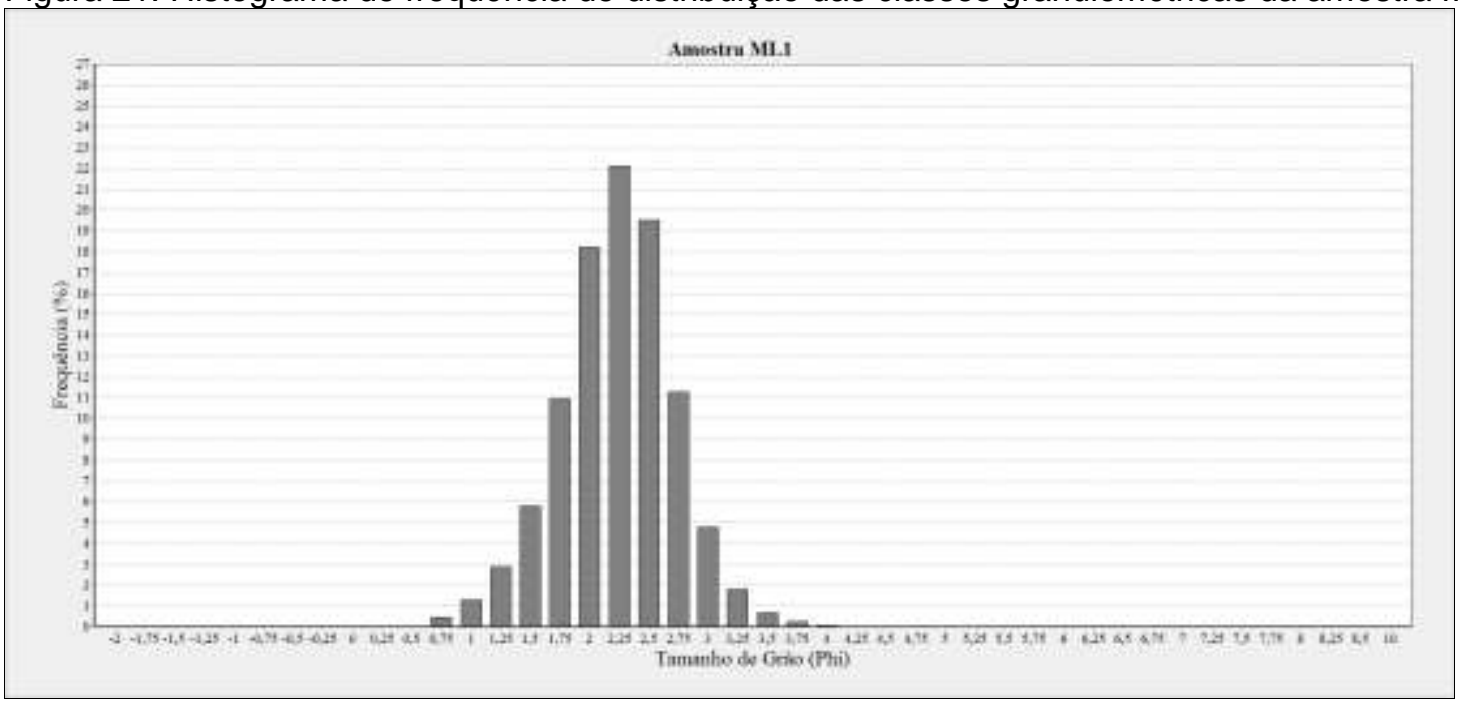

Quadro 13: Medidas de tendência central e dispersão da amostra ML1.

\begin{tabular}{|c|c|c|c|c|c|}
\hline \multirow{2}{*}{$\begin{array}{c}\text { Amostra } \\
\text { ML1 }\end{array}$} & Média & Mediana & Seleção & Assimetria & Curtose \\
\cline { 2 - 6 } & $2,10 \varnothing$ & $2,10 \varnothing$ & $0,47 \varnothing$ & $-0,05$ & 1,06 \\
\hline
\end{tabular}

A amostra LE1 constitui-se de $69,39 \%$ de areia fina; $26,99 \%$ de areia média; $2,28 \%$ de areia muito fina; $1,09 \%$ de areia grossa; $0,16 \%$ de argila; e 0,09\% de coloides. A amostra apresenta sedimentos bem selecionados, com curva mesocúrtica, granulometria média areia fina, assimetria negativa e classificada como areno-argilosa. A Figura 22 apresenta o histograma de distribuição de frequência e o Quadro 14 os valores de tendência central e dispersão.

Figura 22: Histograma de frequência de distribuição das classes granulométricas da amostra LE1. 


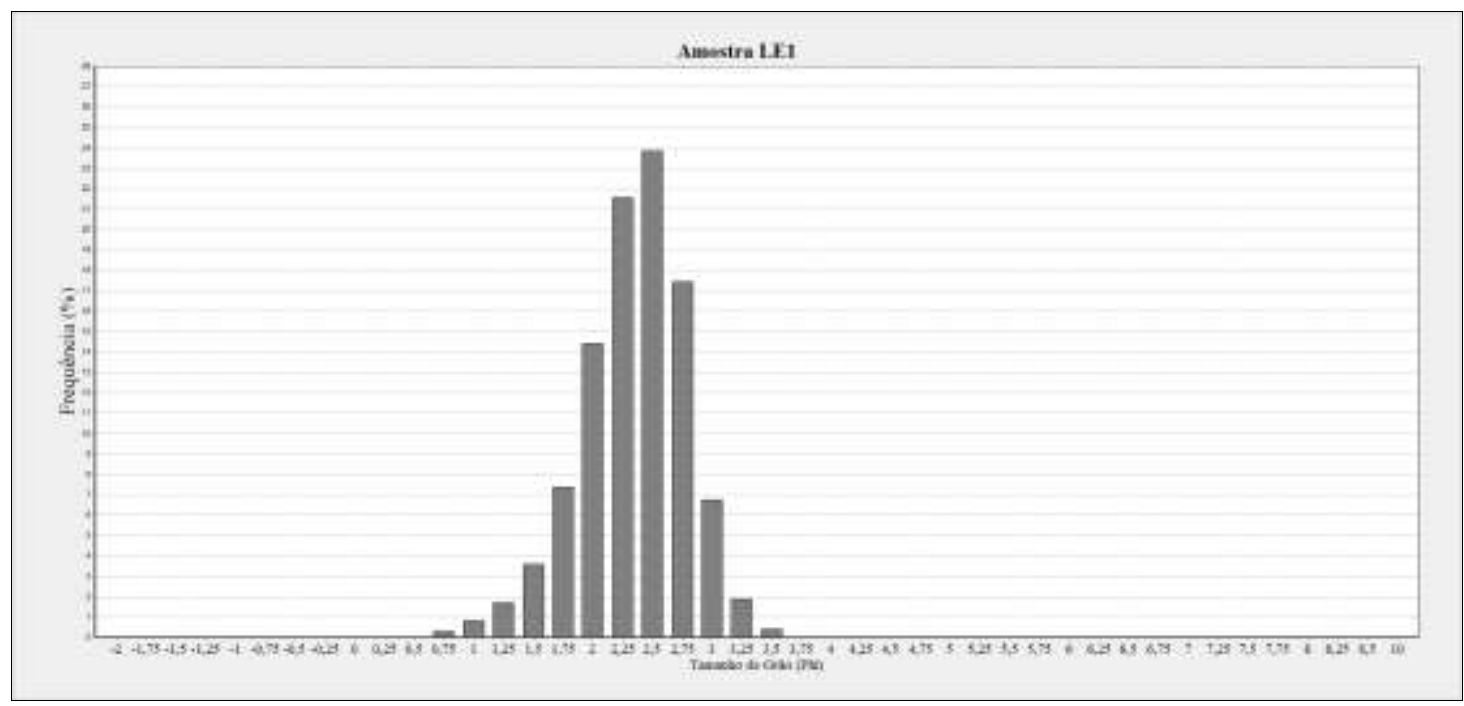

Quadro 14: Medidas de tendência central e dispersão da amostra LE1.

\begin{tabular}{c|c|c|c|c|c|} 
Amostra & Média & Mediana & Seleção & Assimetria & Curtose \\
\cline { 2 - 6 } LE1 & $2,23 \varnothing$ & $2,25 \varnothing$ & $0,44 \varnothing$ & $-0,10$ & 1,06 \\
\hline
\end{tabular}

A amostra LE2 possui $61,68 \%$ de areia fina; $32,94 \%$ de areia média; $3,27 \%$ de areia muito fina; $1,88 \%$ de areia grossa, $0,15 \%$ de argila e $0,08 \%$ de coloides. Esta amostra apresenta sedimentos moderadamente selecionados, com curva mesocúrtica, granulometria média areia fina, aproximadamente simétrica e classificada como areno-argilosa. A Figura 23 apresenta o histograma de distribuição de frequência e o Quadro 15 os valores de tendência central e dispersão.

Figura 23: Histograma de frequência de distribuição das classes granulométricas da amostra LE2.

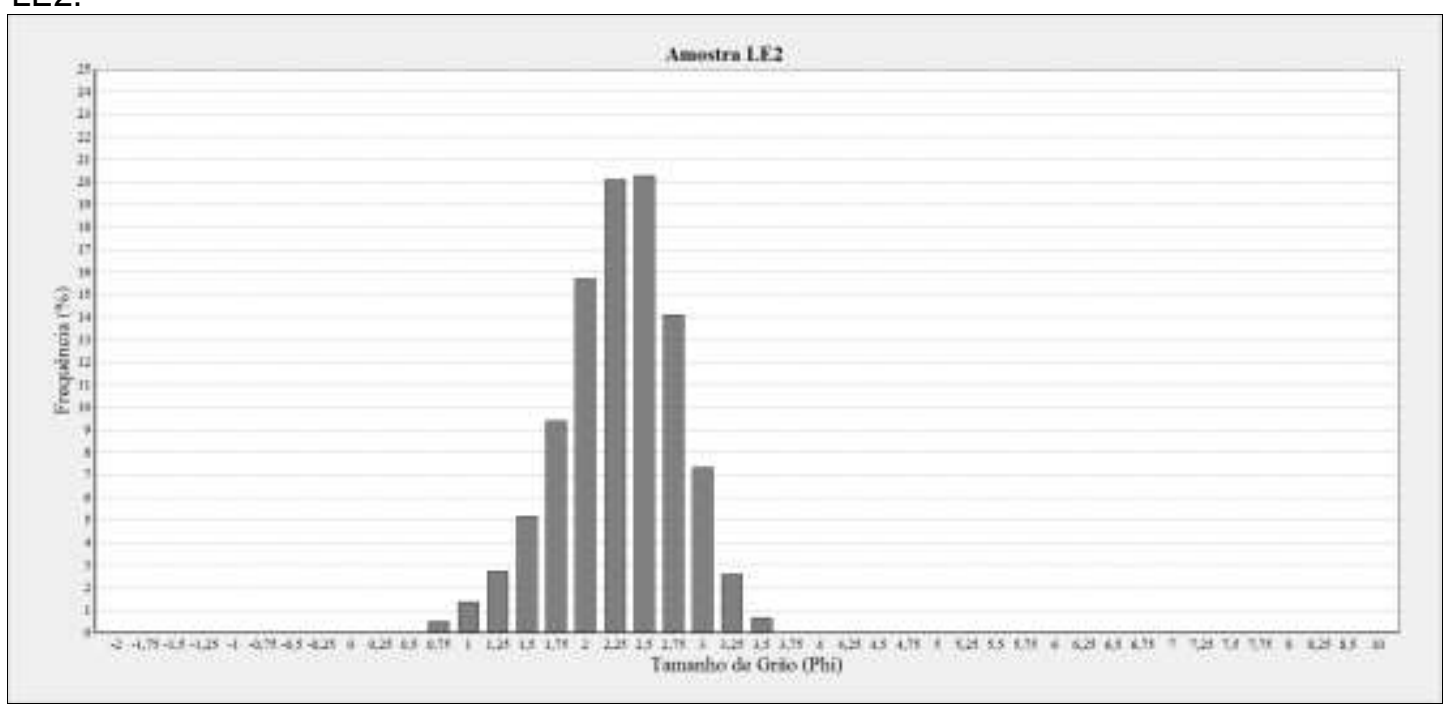

Quadro 15: Medidas de tendência central e dispersão da amostra LE2. 


\begin{tabular}{|c|c|c|c|c|c|}
\hline \multirow{2}{*}{$\begin{array}{c}\text { Amostra } \\
\text { LE2 }\end{array}$} & Média & Mediana & Seleção & Assimetria & Curtose \\
\cline { 2 - 6 } & $2,17 \varnothing$ & $2,18 \varnothing$ & $0,50 \varnothing$ & $-0,07$ & 1,05 \\
\hline
\end{tabular}

A amostra F1 consiste de $67,91 \%$ de areia fina; $26,82 \%$ de areia média; $4,50 \%$ areia muita fina; $0,77 \%$ de areia grossa. A amostra apresenta sedimentos bem selecionados, com curva mesocúrtica, granulometria média areia fina, assimetria aproximadamente simétrica e classificada como arenosa. A Figura 24 apresenta o histograma de distribuição de frequência e o Quadro 16 os valores de tendência central e dispersão.

Figura 24: Histograma de frequência de distribuição das classes granulométricas da amostra F1.

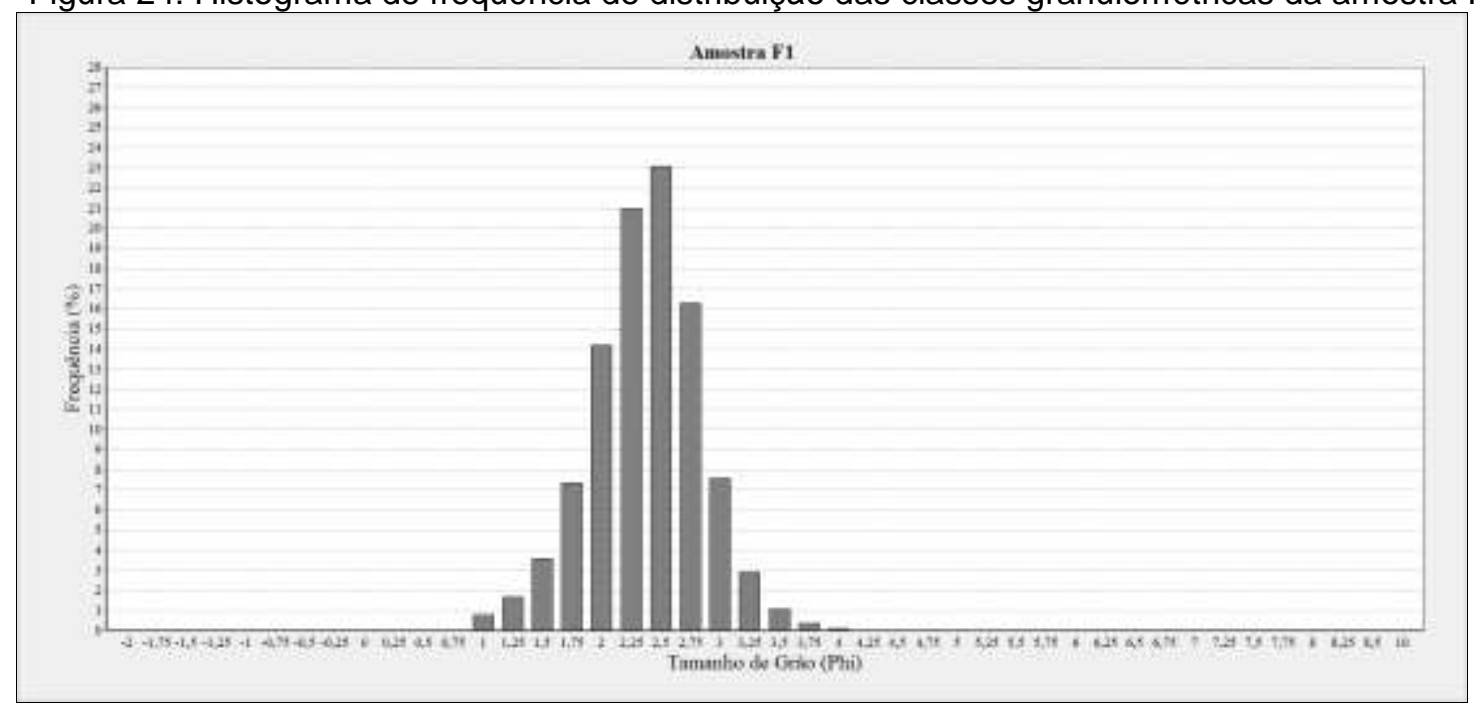

Quadro 16: Medidas de tendência central e dispersão da amostra F1.

\begin{tabular}{|c|c|c|c|c|c|}
\hline \multirow{2}{*}{$\begin{array}{c}\text { Amostra } \\
\text { F1 }\end{array}$} & Média & Mediana & Seleção & Assimetria & Curtose \\
\cline { 2 - 6 } & $2,25 \varnothing$ & $2,26 \varnothing$ & $0,45 \varnothing$ & $-0,06$ & 1,06 \\
\hline
\end{tabular}

O Depósito marinho praial na área de estudo está presente também na forma de cordões litorâneos, sendo por vezes recobertos por sedimentos eólicos. Este depósito marca a fase regressiva da linha de costa durante os eventos transgressivo-regressivos ao longo do Holoceno (Figura 25).

As características texturais dos sedimentos marinhos da área de estudo, que constituem o Depósito marinho praial na forma de cordões litorâneos, são correlacionáveis aos sedimentos do mesmo depósito em forma de praia. A amostra LE4 constitui-se, predominantemente, de $64,59 \%$ de areia fina; $30,83 \%$ de areia 
média; $2,79 \%$ areia muito fina; $1,56 \%$ areia grossa; e $0,23 \%$ de argila. O histograma de distribuição (Figura 26) e os valores de tendência central e dispersão (Quadro 17), mostram que a amostra LE4 apresenta sedimentos bem selecionados, curva mesocúrtica, granulometria média areia fina e, aproximadamente simétrica. Esta amostra classifica-se como areno-argilosa.

Figura 25: (A) Detalhe do Depósito marinho praial constituído de sedimentos arenosos, bem selecionados, com presença de matéria orgânica; (B) Vista para sudeste do Depósito marinho praial em forma de cordão regressivo.

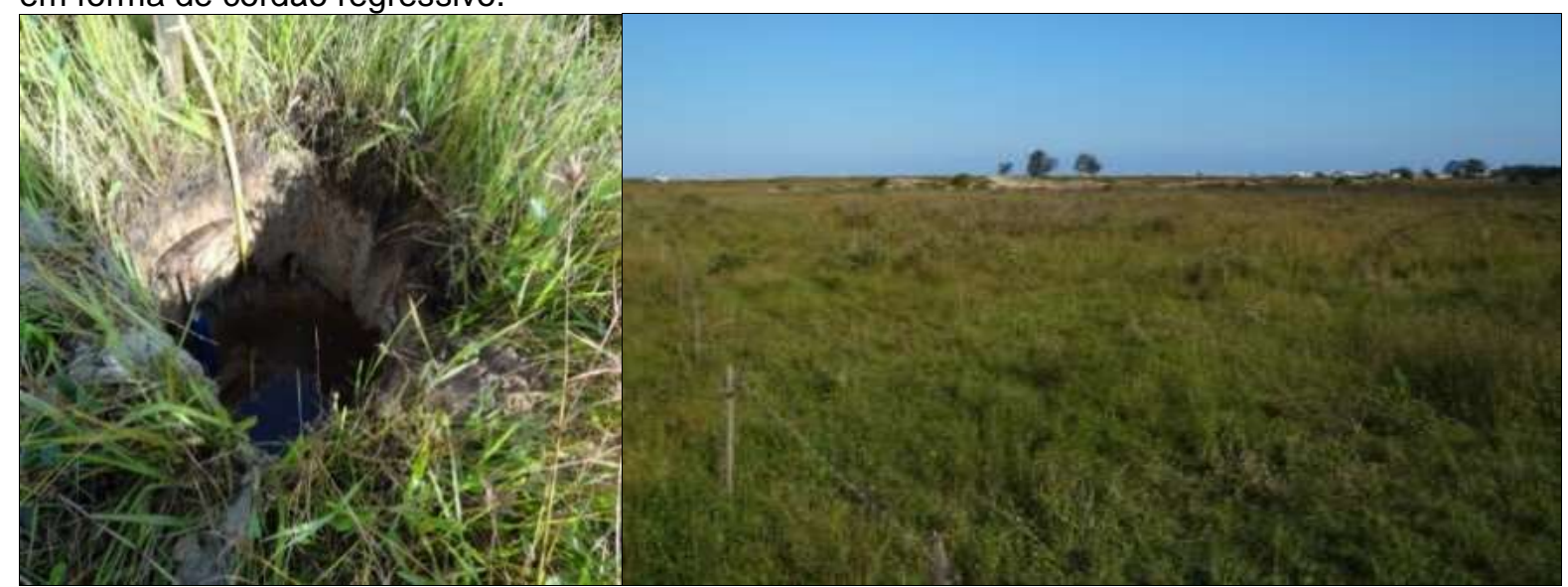

Fonte: Aline Pires Mateus, Janeiro de 2016.

Figura 26: Histograma de frequência de distribuição das classes granulométricas da amostra LE4.

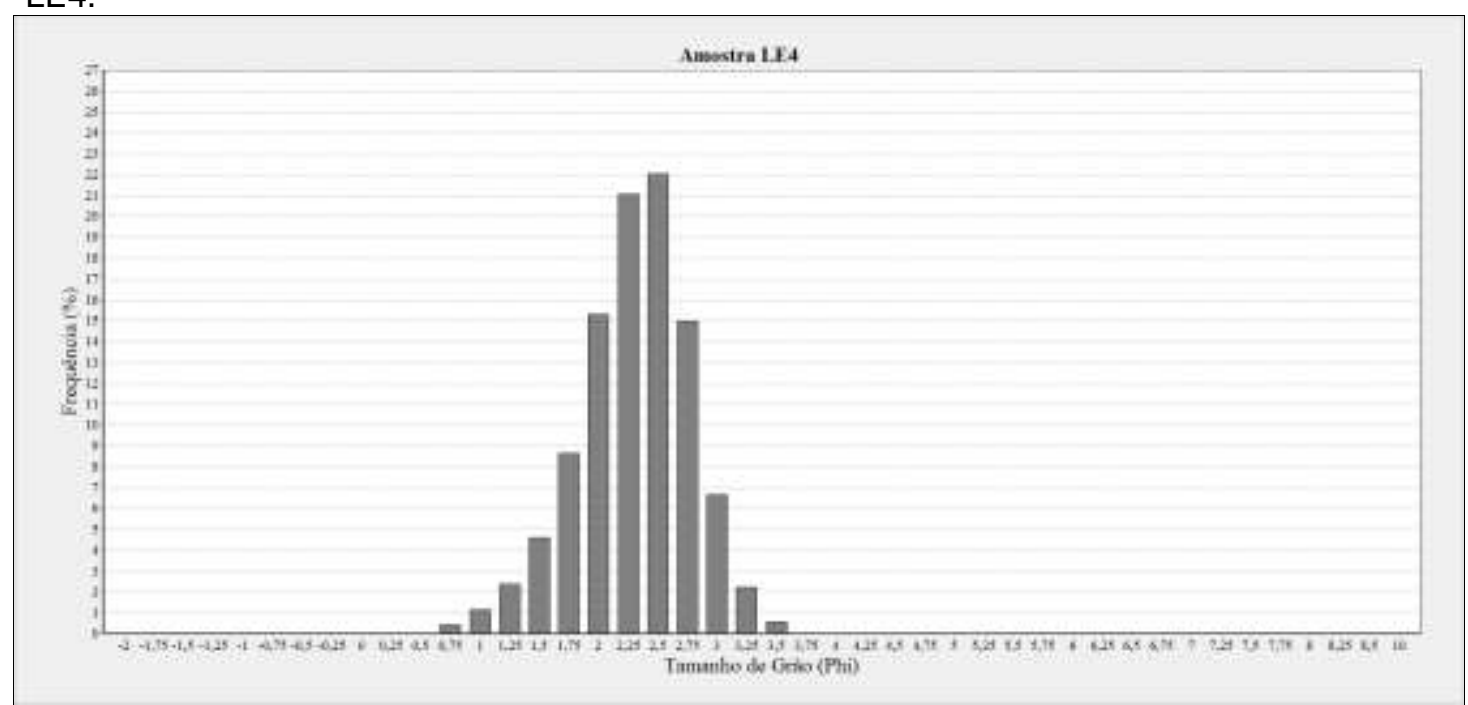

Quadro 17: Medidas de tendência central e dispersão da amostra LE4. 


\begin{tabular}{|c|c|c|c|c|c|}
\hline \multirow{2}{*}{$\begin{array}{c}\text { Amostra } \\
\text { LE4 }\end{array}$} & Média & Mediana & Seleção & Assimetria & Curtose \\
\cline { 2 - 6 } & $2,19 \varnothing$ & $2,21 \varnothing$ & $0,47 \varnothing$ & $-0,08$ & 1,07 \\
\hline
\end{tabular}

A amostra F3 apresenta 69,09\% de areia fina; 27,24\% de areia média; 2,64\% de areia muito fina; $0,78 \%$ areia grossa; $0,16 \%$ de argila; e $0,09 \%$ de coloides. $A$ amostra apresenta sedimentos bem selecionados, com curva mesocúrtica, granulometria média areia fina, aproximadamente simétrica e classificada como areno-argilosa. A Figura 27 apresenta o histograma de distribuição de frequência e o Quadro 18 os valores de tendência central e dispersão.

Figura 27: Histograma de frequência de distribuição das classes granulométricas da amostra F3.

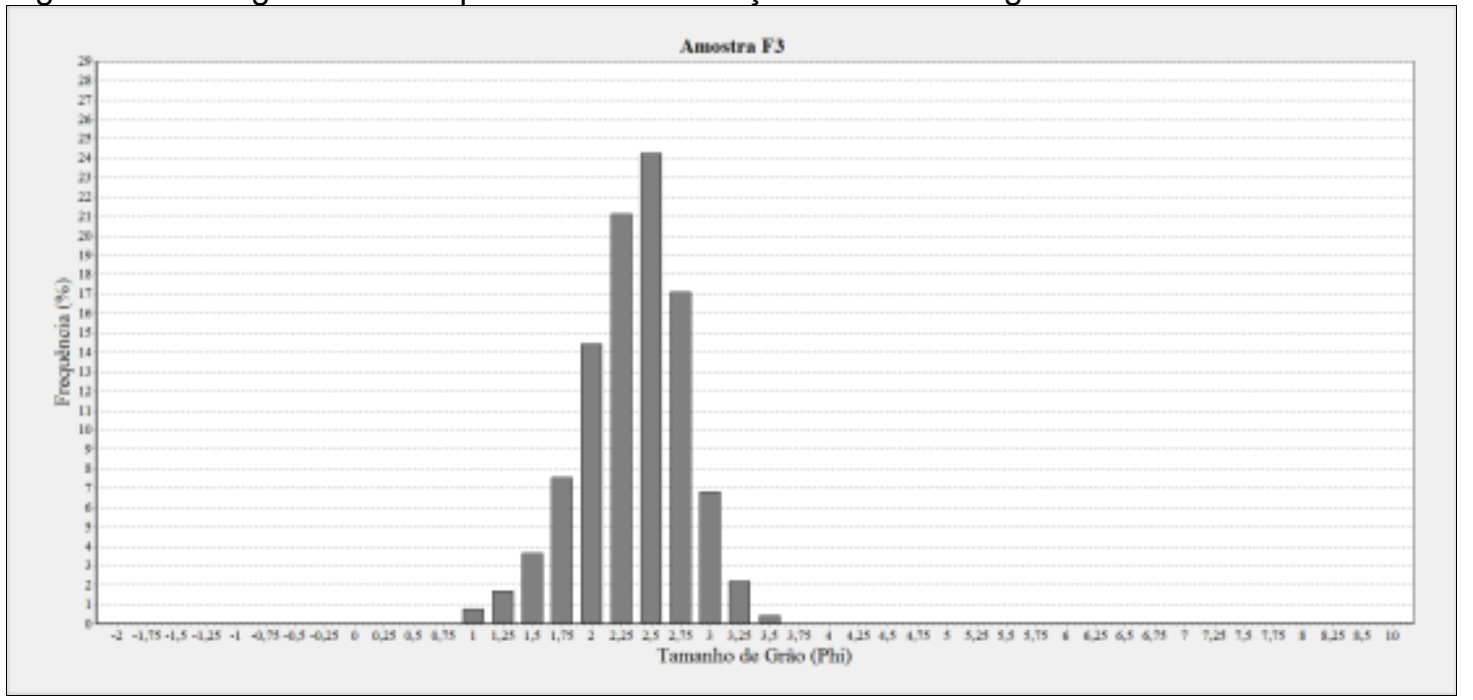

Quadro 18: Medidas de tendência central e dispersão da amostra F3.

\begin{tabular}{|c|c|c|c|c|c|}
\hline \multirow{2}{*}{$\begin{array}{c}\text { Amostra } \\
\text { F3 }\end{array}$} & Média & Mediana & Seleção & Assimetria & Curtose \\
\cline { 2 - 6 } & $2,26 \varnothing$ & $2,25 \varnothing$ & $0,44 \varnothing$ & $-0,09$ & 1,06 \\
\hline
\end{tabular}

\section{Depósito lagunar praial}

O Depósito lagunar praial (Figura 28) caracteriza-se por sedimentos depositados nas margens dos corpos lagunares em ambientes de alta energia pela ondulação oriunda da ação do vento sobre estes corpos, bem como pela diminuição do nível da lagoa que por consequência expôs depósitos que anteriormente estavam encobertos pela lâmina de água. $\mathrm{Na}$ área de estudo o Depósito lagunar praial está presente na margem norte da lagoa dos Esteves e em partes da margem oeste e sul; na lagoa do Faxinal, na margem oeste e em partes da margem leste e na lagoa Mãe Luzia em toda margem lagunar. 
Figura 28: (A) Detalhe da seção colunar do Depósito lagunar praial da lagoa Faxinal; (B) Vista geral da praia da lagoa Faxinal.

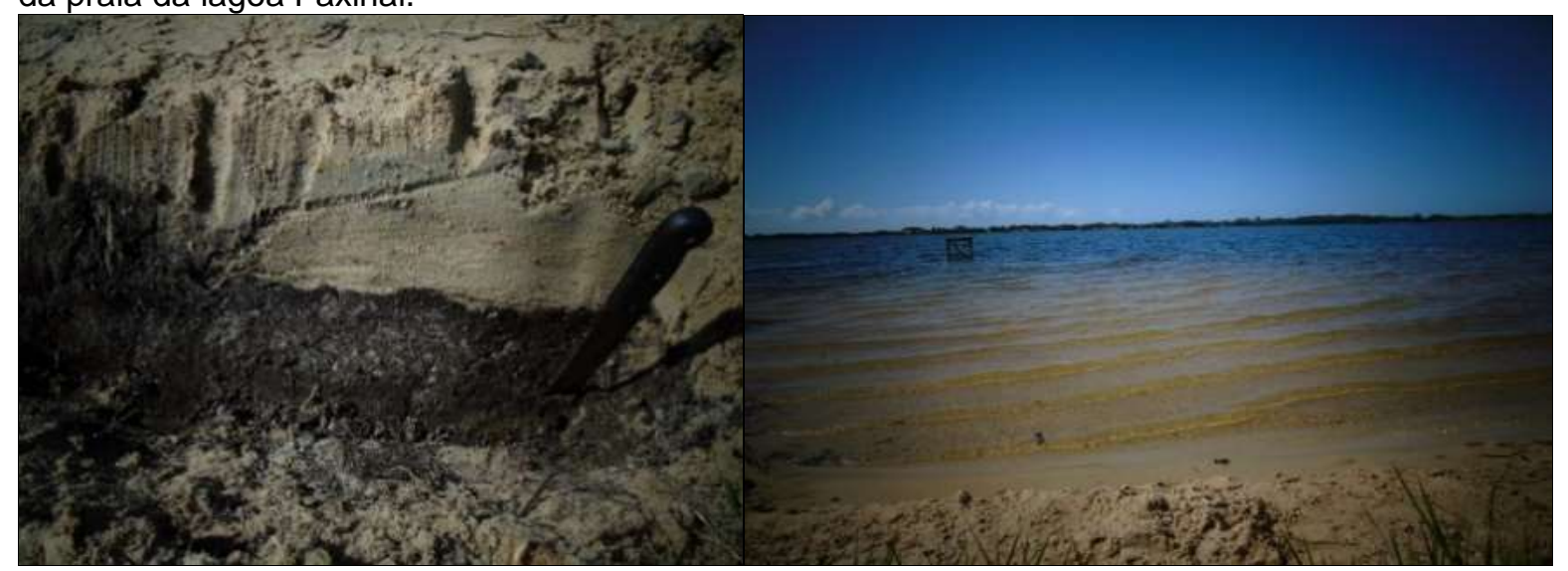

Fonte: Aline Pires Mateus, Janeiro de 2016.

Na estação F6 (praia da lagoa Faxinal) foram coletadas duas amostras, sendo a amostra F6a mais superficial, típica do ambiente lagunar praial, e a amostra F6b, subsuperficial, exibindo características de ambiente lagunar em forma de terraço lagunar, representando um ambiente anteriormente ocupado pelo corpo lagunar.

A amostra F6a apresenta 54,45\% de areia média; $32,38 \%$ de areia grossa; $11,81 \%$ de areia fina; e $1,36 \%$ de areia muito grossa. A amostra apresenta sedimentos moderadamente selecionados, com curva mesocúrtica, granulometria média areia média, assimetria positiva e classificada como arenosa. A Figura 29 apresenta o histograma de distribuição de frequência e o Quadro 19 os valores de tendência central e dispersão.

Figura 29: Histograma de frequência de distribuição das classes granulométricas da amostra F6a.

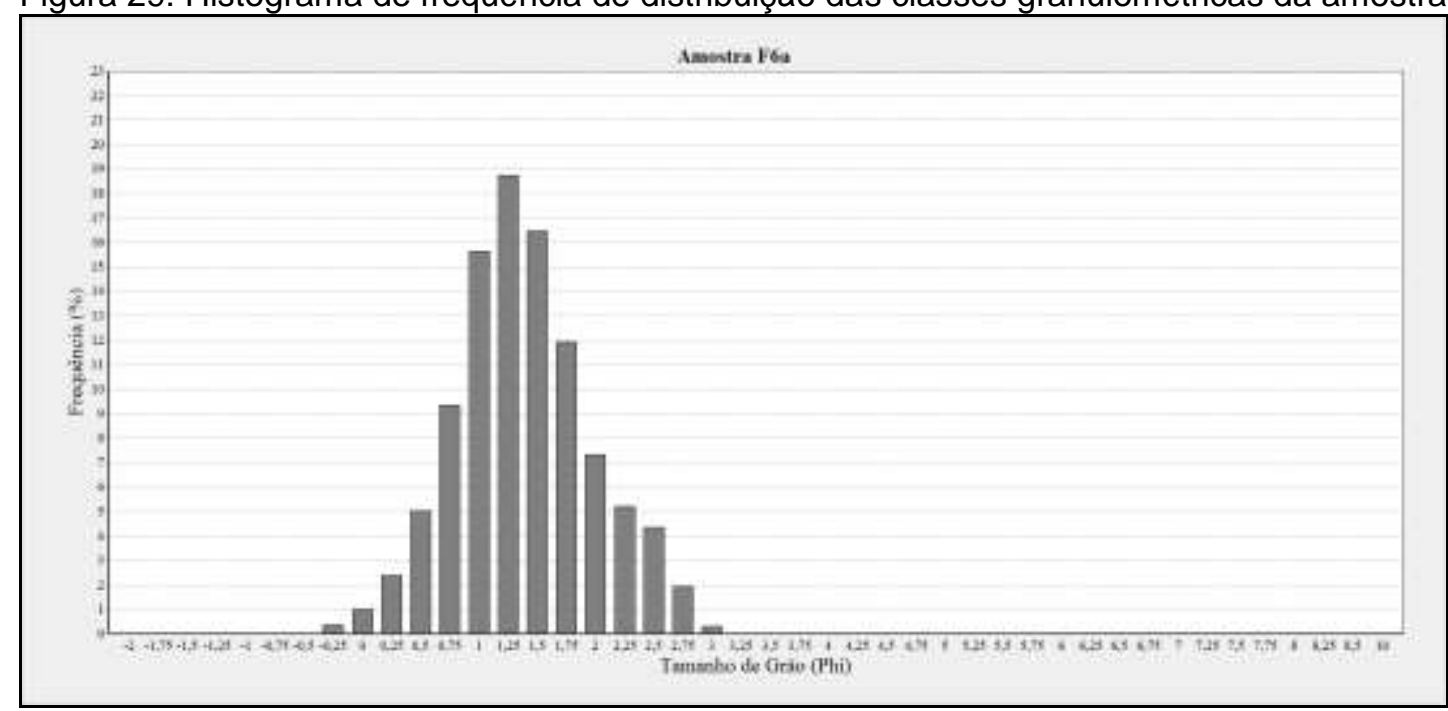

Quadro 19: Medidas de tendência central e dispersão da amostra F6a. 


\begin{tabular}{|c|c|c|c|c|c|}
\hline \multirow{2}{*}{$\begin{array}{c}\text { Amostra } \\
\text { F6a }\end{array}$} & Média & Mediana & Seleção & Assimetria & Curtose \\
\cline { 2 - 6 } & $1,25 \varnothing$ & $1,21 \varnothing$ & $0,59 \varnothing$ & 0,10 & 1,08 \\
\hline
\end{tabular}

A amostra F6b contém 54,07\% de areia média; 35,01\% de areia fina; 9,37\% de areia grossa; $1,49 \%$ de areia muito fina; e 0,06\% de areia muito grossa. O teor de matéria orgânica dessa amostra é de 1,89\%. Esta amostra apresenta sedimentos moderadamente selecionados, com curva mesocúrtica, granulometria média areia média, assimetria aproximadamente simétrica e classificada como arenosa. A Figura 30 apresenta o histograma de distribuição de frequência e o Quadro 20 os valores de tendência central e dispersão.

Figura 30: Histograma de frequência de distribuição das classes granulométricas da amostra F6b.

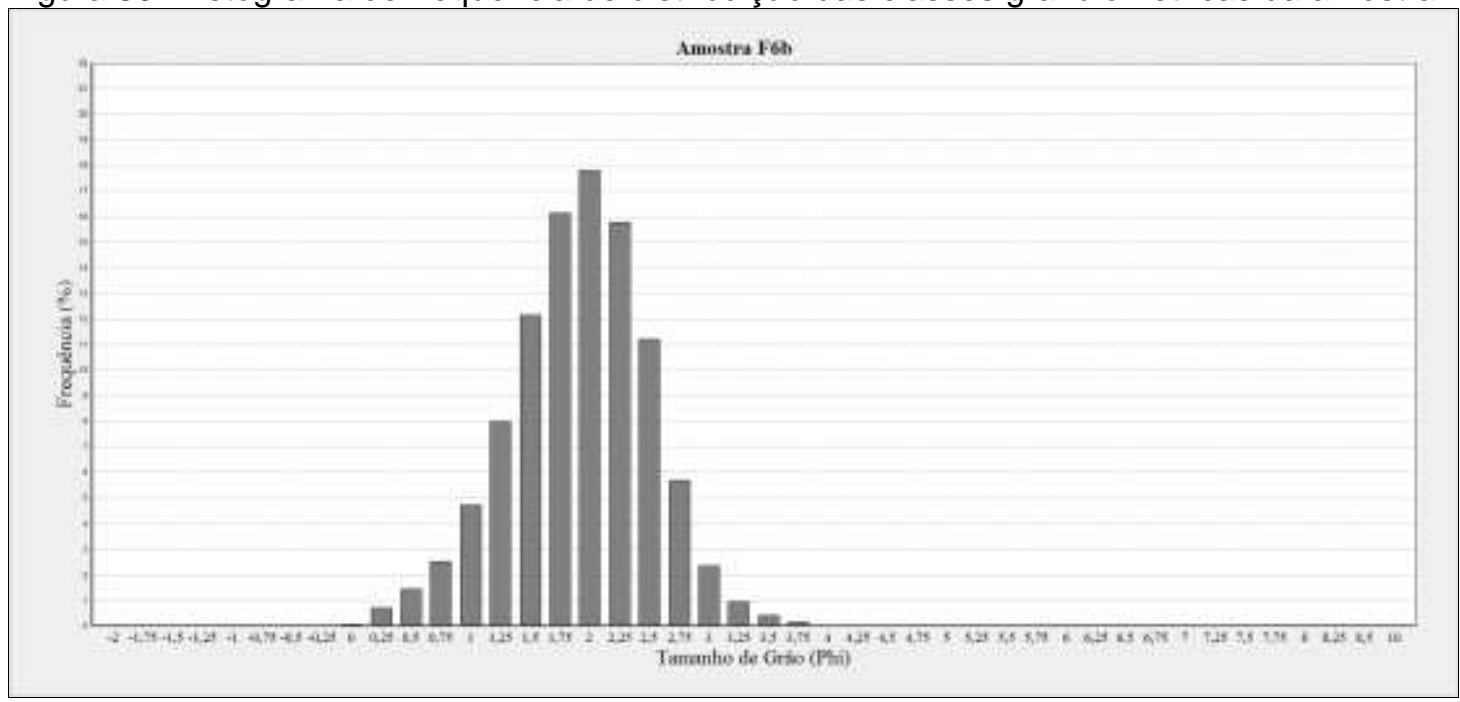

Quadro 20: Medidas de tendência central e dispersão da amostra F6b.

\begin{tabular}{|c|c|c|c|c|c|}
\hline \multirow{2}{*}{$\begin{array}{c}\text { Amostra } \\
\text { F6b }\end{array}$} & Média & Mediana & Seleção & Assimetria & Curtose \\
\cline { 2 - 6 } & $1,79 \varnothing$ & $1,81 \varnothing$ & $0,58 \varnothing$ & $-0,06$ & 1,02 \\
\hline
\end{tabular}

A amostra LE6 constitui-se de $58,12 \%$ de areia grossa; $40,31 \%$ de areia média; $1,21 \%$ de areia muito grossa; e $0,36 \%$ de areia fina. Esta amostra apresenta sedimentos bem selecionados, com curva mesocúrtica, granulometria média areia grossa, aproximadamente simétrica e classificada como arenosa. A Figura 31 apresenta o histograma de distribuição de frequência e o Quadro 21 os valores de tendência central e dispersão.

Figura 31: Histograma de frequência de distribuição das classes granulométricas da amostra LE6. 


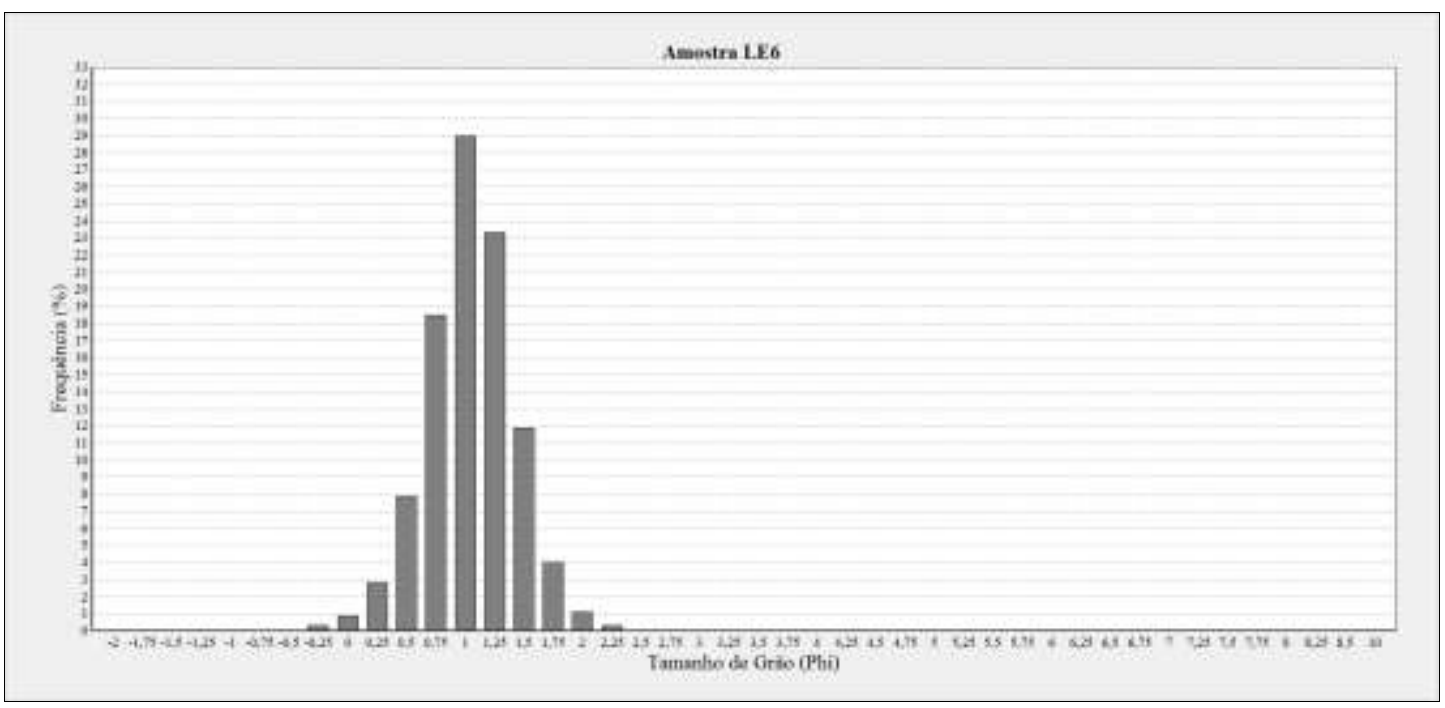

Quadro 21: Medidas de tendência central e dispersão da amostra LE6.

\begin{tabular}{|c|c|c|c|c|c|}
\hline \multirow{2}{*}{$\begin{array}{c}\text { Amostra } \\
\text { LE6 }\end{array}$} & Média & Mediana & Seleção & Assimetria & Curtose \\
\cline { 2 - 6 } & $0,91 \varnothing$ & $0,91 \varnothing$ & $0,36 \varnothing$ & $-0,01$ & 1,04 \\
\hline
\end{tabular}

A amostra ML6 apresenta $54,43 \%$ de areia média; $30,04 \%$ de areia fina; $13,57 \%$ de areia grossa; $1,46 \%$ areia muito fina; e $0,50 \%$ de areia muito grossa. $O$ teor de matéria orgânica dessa amostra é de 0,28\%. A amostra apresenta sedimentos moderadamente selecionados, com curva mesocúrtica, granulometria média areia média, assimetria aproximadamente simétrica e classificada como arenosa. A Figura 32 apresenta o histograma de distribuição de frequência e o Quadro 22 os valores de tendência central e dispersão.

Figura 32: Histograma de frequência de distribuição das classes granulométricas da amostra ML6.

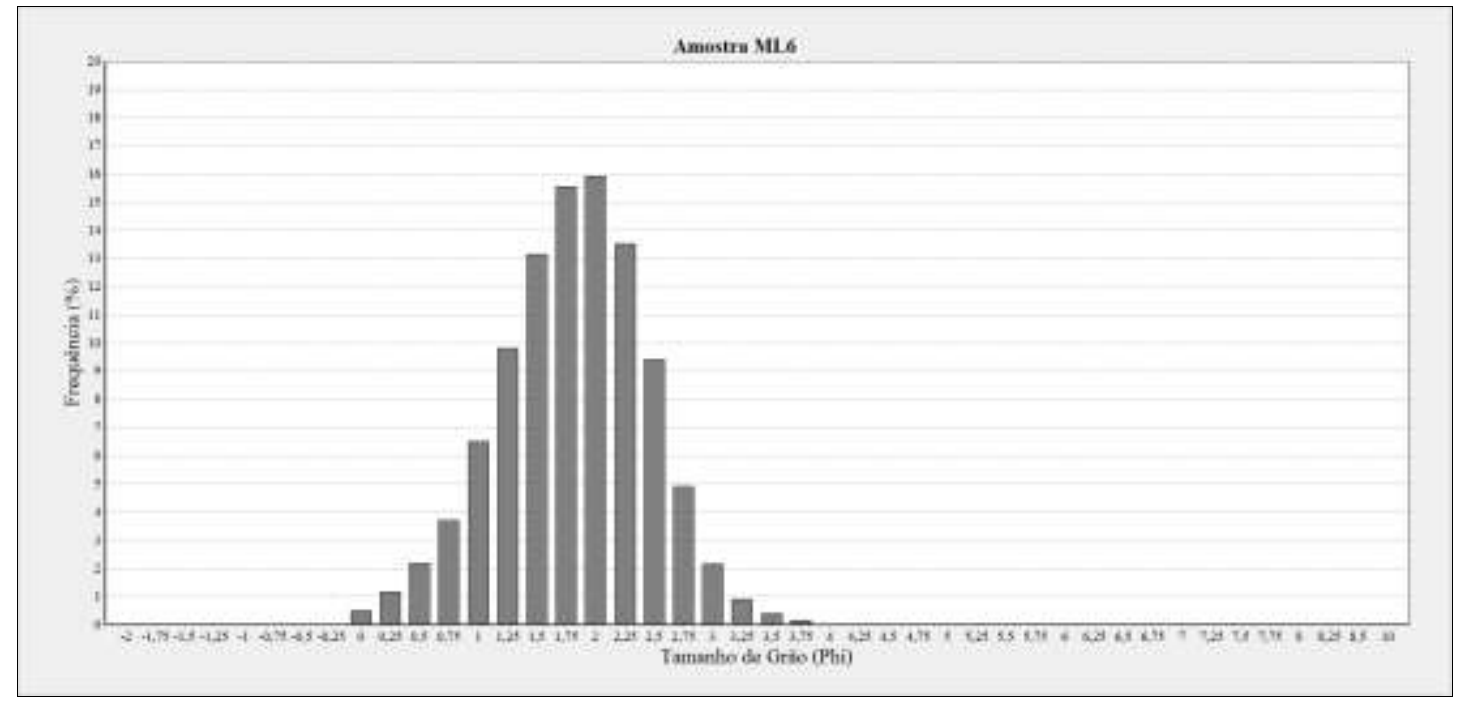


Quadro 22: Medidas de tendência central e dispersão da amostra ML6.

\begin{tabular}{|c|c|c|c|c|c|}
\hline \multirow{2}{*}{$\begin{array}{c}\text { Amostra } \\
\text { ML6 }\end{array}$} & Média & Mediana & Seleção & Assimetria & Curtose \\
\cline { 2 - 6 } & $1,68 \varnothing$ & $1,70 \varnothing$ & $0,63 \varnothing$ & $-0,06$ & 1,01 \\
\hline
\end{tabular}

Cartografia dos valores de tendência central e dispersão dos sedimentos

Os valores de média e mediana de tamanho dos grãos das amostras coletadas foram designados conforme sua classificação em: areia fina, areia média e areia grossa; os valores de desvio padrão (selecionamento) foram classificados em bem selecionados, moderadamente selecionados e pobremente selecionados; e, os valores de assimetria foram classificados em aproximadamente simétrica, negativa, positiva e muito positiva.

Conforme pode ser observado na Figura 33, a classe areia fina predomina na barreira IV e, em uma pequena mancha na porção oeste da lagoa dos Esteves, que corresponde ao Depósito lagunar em forma de terraço lagunar.

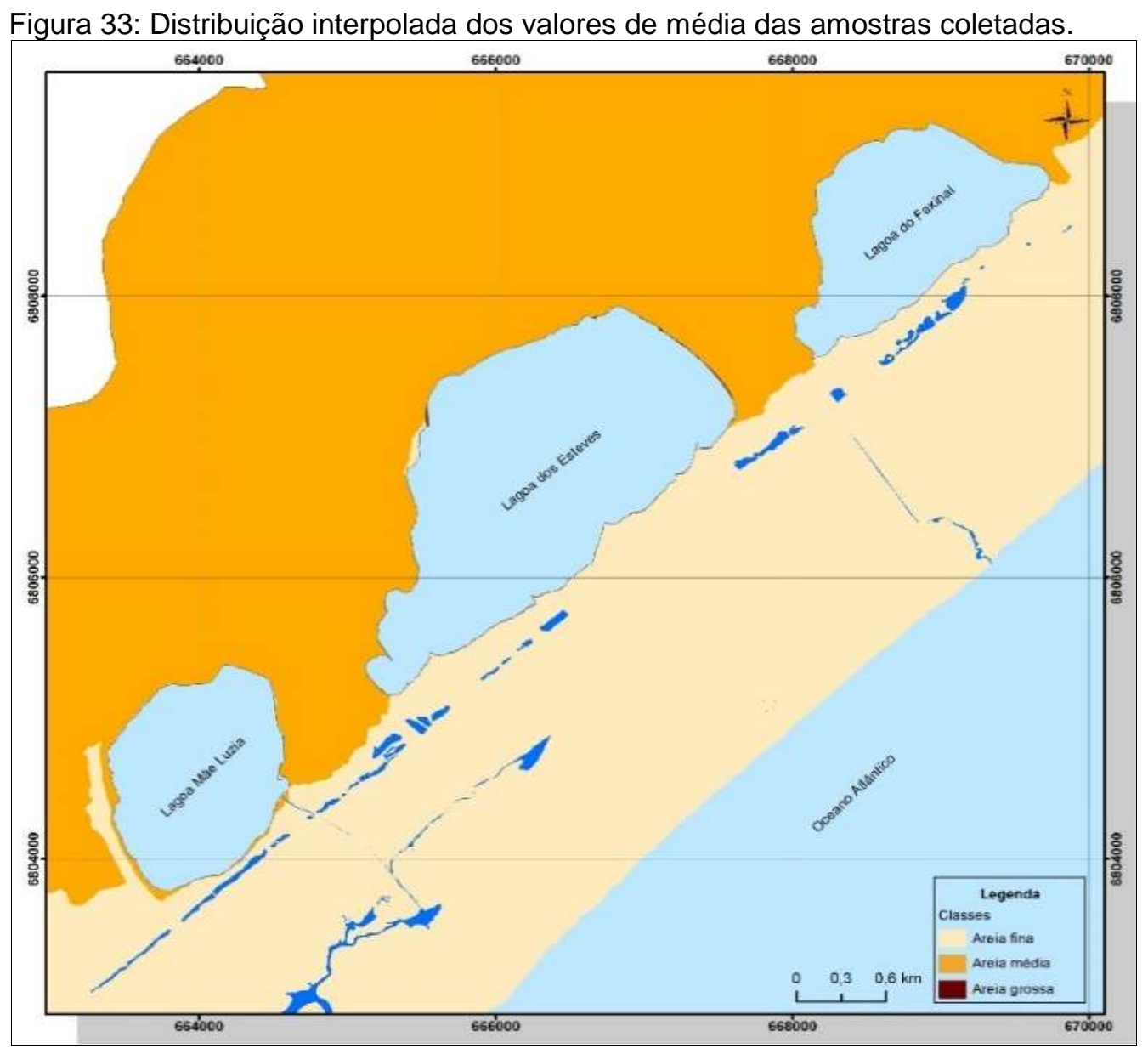

A classe areia média está presente nas imediações da lagoa do Faxinal e, em uma pequena porção nas proximidades da lagoa Mãe Luzia. A barreira III, que aflora 
no entorno da área de estudo (Figura 33), é representada pela classe areia média. $\mathrm{Na}$ porção oeste da lagoa dos Esteves, e um setor restrito, representando o Depósito lagunar praial, tem-se a classe areia grossa. Dessa forma, a partir de uma análise prévia, observa-se que a média dos sedimentos disponibilizados da plataforma continental interna para a costa pertencem a classe areia fina, caracterizando o setor morfológico de pós-praia da área de estudo. Estes sedimentos, posteriormente, são fonte para a formação do Depósito eólico que cobre parte da área de estudo.

A média dos sedimentos depositados nas margens das lagoas ou que em algum momento foram expostos pela diminuição da lâmina de água, pertencem a classe areia grossa na praia da lagoa dos Esteves e, a classe areia média nas praias das lagoas do Faxinal e Mãe Luzia.

De acordo com a Figura 34 a maior parte dos sedimentos que formam os depósitos da barreira IV apresentam-se bem selecionados, com exceção a uma amostra que representa o Depósito marinho praial localizado perpendicularmente à lagoa dos Esteves, que foi classificado como moderadamente selecionado. A amostra supracitada em conjunto com as amostras que representam os depósitos lagunar praial (nas imediações da lagoa do Faxinal e Mãe Luzia) e lagunar (entre as lagoas do Faxinal e Esteves e Mãe Luzia e Esteves) apresentam sedimentos moderadamente selecionados. A barreira III também apresenta sedimentos moderadamente selecionados.

Pobremente selecionados apresentam-se os sedimentos do Depósito fluvial e do Depósito lagunar nas proximidades oeste da lagoa dos Esteves e sudoeste da lagoa Mãe Luzia. Sedimentos pobremente selecionados são típicos de ambientes de menor energia e hidrodinâmica, ao contrário dos depósitos bem selecionados que são formados em ambientes mais dinâmicos e com energia mais elevada. 
Figura 34: Distribuição interpolada dos valores de desvio padrão das amostras coletadas.

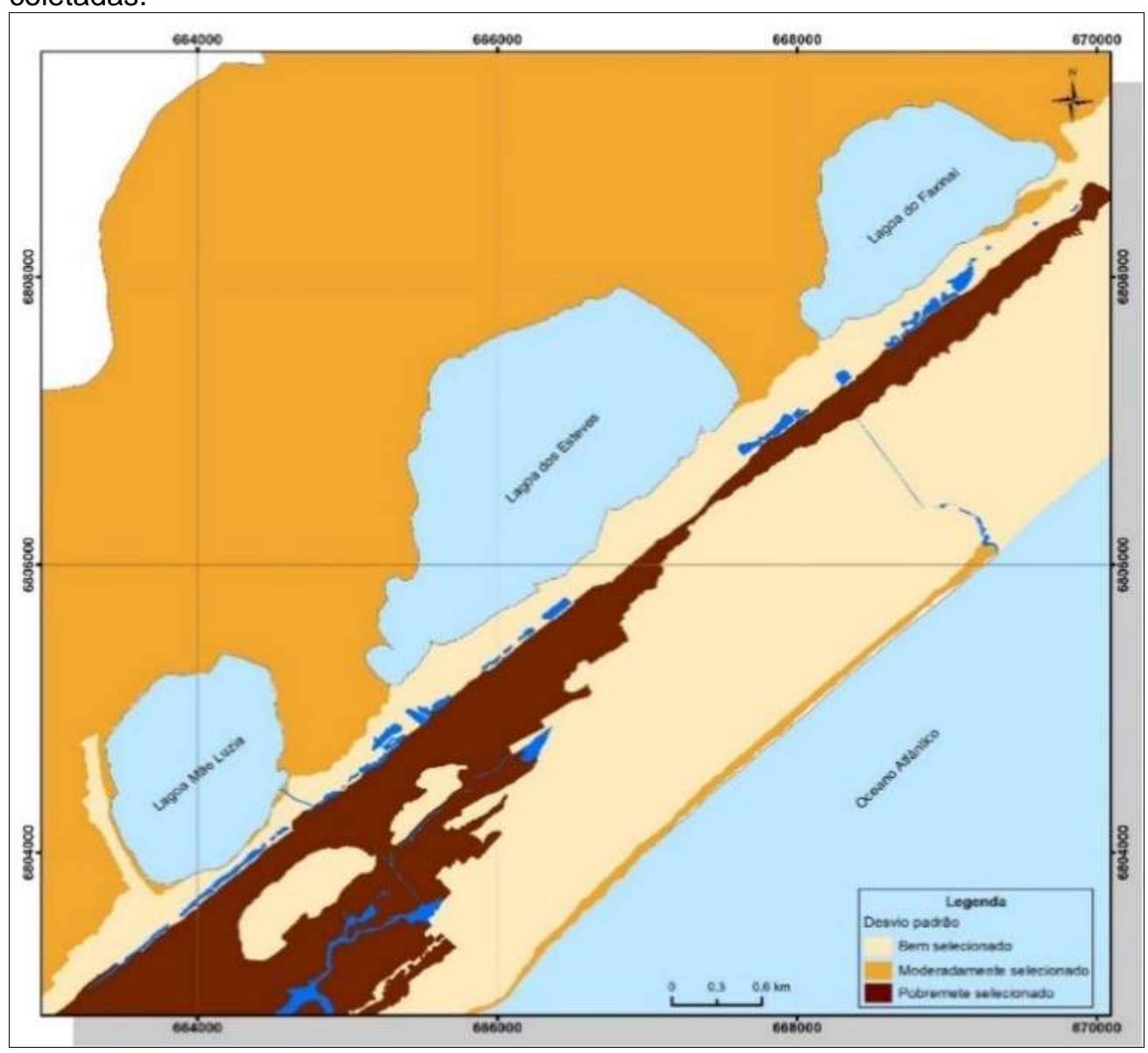

A Figura 35 apresenta a assimetria dos sedimentos das amostras coletadas. Conforme pode ser observado, a maior parte da área de estudo apresenta curva aproximadamente simétrica. Na porção norte e sudoeste da lagoa do Faxinal e oeste da lagoa Mãe Luzia, as curvas apresentam-se positiva, ou seja, com enriquecimento da população granulométrica em sedimentos mais finos. Na porção próxima à linha de costa perpendicular à lagoa dos Esteves, na porção sudeste e, à oeste da lagoa dos Esteves, as curvas se apresentam muito positiva. As curvas com assimetria negativa, isto é, com aporte para sedimentos mais grosseiros, apresentam-se nas amostras que representam o Depósito marinho praial próximo à linha de costa e entre a lagoa do Faxinal e o oceano.

Figura 35: Distribuição interpolada dos valores de assimetria das amostras coletadas. 


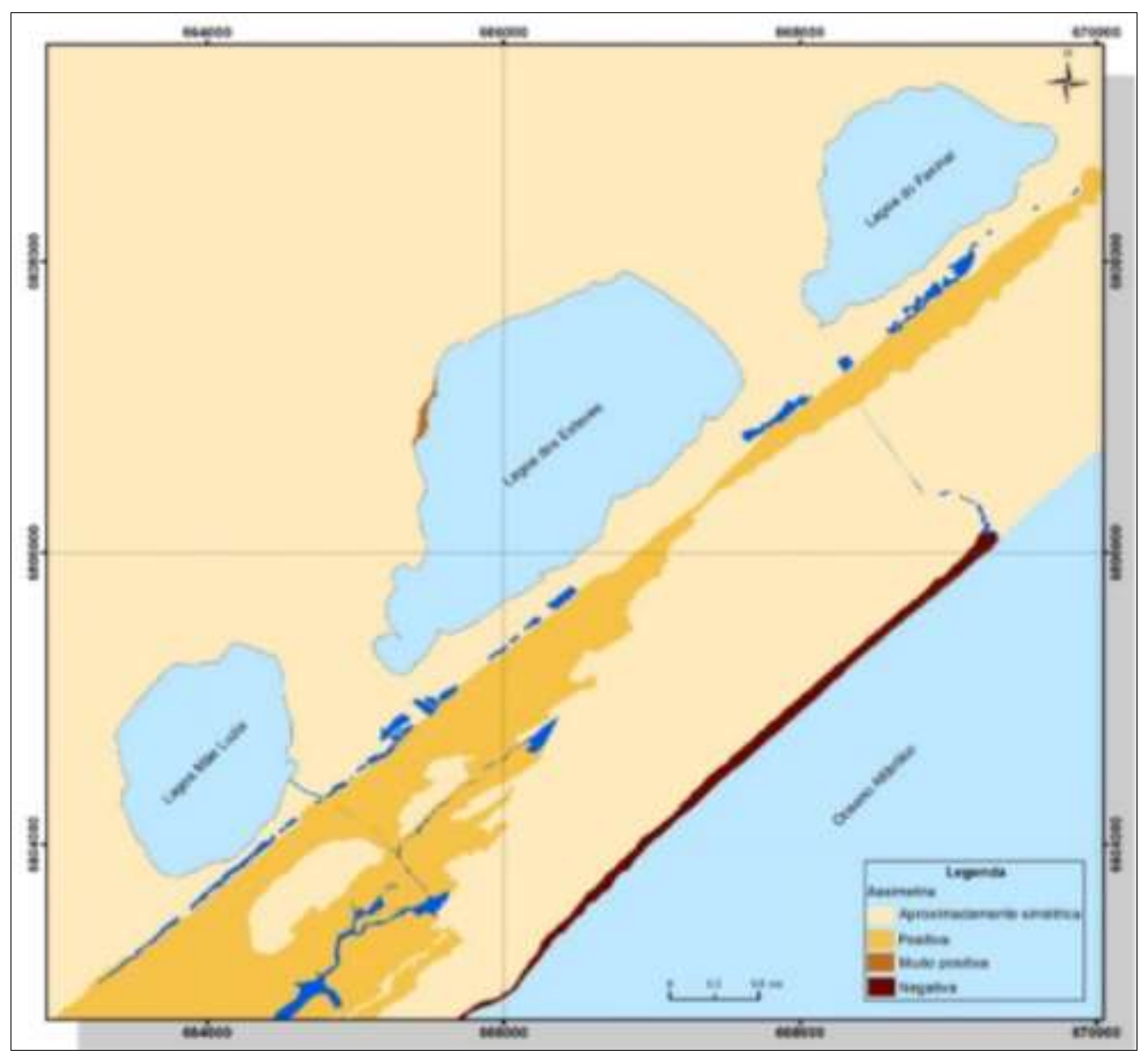

\section{Considerações Finais}

A planície costeira, predominantemente holocênica, na região das lagoas dos Esteves, Faxinal e Mãe Luzia, atualmente, constitui-se do ponto de vista geológicogeomorfológico, de dois subsistemas: o lagunar, que se institui em sua maior parte pelas lagoas dos Esteves, Faxinal e Mãe Luzia (retro barreira/backbarrier); e, a barreira, que se institui pelos depósitos dispostos entre as lagoas e o oceano (barreira arenosa). Este sistema deposicional se formou durante a última transgressão-regressão que ocorreu nos últimos 5,1 Ka AP na costa brasileira.

A área de barreira compõe-se de depósitos eólico e marinho praial do sistema deposicional transicional. O Depósito eólico está presente em forma de dunas fixas, semifixas e móveis. Os sedimentos deste depósito configuram-se como bem selecionados, com ausência de matéria orgânica, uma vez que, estão situados em ambientes de média a alta energia. Já o Depósito marinho praial se apresenta na forma de praia, correspondendo a praia atual, e na forma de cordões litorâneos, relacionado a fase regressiva da linha de costa.

$\mathrm{Na}$ área de retro barreira estão situadas as lagoas dos Esteves, Faxinal e Mãe Luzia e o Depósito lagunar, do sistema deposicional transicional. Este depósito 
localiza-se entre as lagoas, marcando possíveis paleocanais de ligação entre as mesmas, bem como à leste e sudeste das lagoas dos Esteves e Mãe Luzia. Este depósito constitui-se de sedimentos pobremente selecionados, apresentando classes de areia fina à areia grossa.

Também ocorre na área de estudo o Depósito fluvial que pertence ao sistema deposicional continental. A dinâmica de transporte e deposição dos sedimentos deste depósito dependem da energia fluvial, ou seja, está área caracteriza-se por um paleocanal, possivelmente do rio Araranguá, que atualmente desemboca à sudeste da área de estudo. O Depósito fluvial está situado paralelamente à linha de costa entre os depósitos eólico, lagunar e marinho praial. Os sedimentos caracterizam-se como pobremente selecionados, típico deste ambiente.

\section{REFERÊNCIAS}

BIGARELLA, J. J. 1965. Subsídios para o estudo das variações do nível oceânico no Quaternário brasileiro. Academia Brasileira de Ciências, 37:263-278.

BOYD, R.; DALRYMPLE, R. W.; ZAITLIN, B. A. 1992. Classification of clastic coastal depositional environments. Sedimentary Geology, 80:139-150.

BRANNER, J. C. 1904. The stone reefs of Brazil, their geological and geographical relations. Bull. Mus. Cmp. Zool. Harvard College, 44, Geol. Ser.7.

CURRAY, J. R. 1964. Transgressions and regressions. In: MILLER, R.L. (Ed.), Papers

DAVIS, J. L. \& ANNAN, A. P. 1989. Ground-penetrating radar for high resolution mapping of soil and rock stratigraphy. Geophysical Prospecting, 37:531-551.

HARTT, C. F. 1870. Geology and physical geography of Brazil. Boston, Fields, Osgood \& Co., 620p.

HORN FILHO, N. O. \& DIEHL, F. L. 1994. Geologia da planície costeira de Santa Catarina. Alcance, 1(1):95-102.

HORN FILHO, N. O. \& DIEHL, F. L. 2001. Geologia da planície costeira de Santa Catarina, Brasil. In: CONGRESSO DO QUATERNÁRIO DE PAÍSES DE LÍNGUAS IBÉRICAS, 1., Lisboa, 2001. Actas... Lisboa: GTPEQ, AEQUA, SGP, p.203-206.

HORN FILHO, N. O. 2003. Setorização da província costeira de Santa Catarina em base aos aspectos geológicos, geomorfológicos e geográficos. Geosul, 18(35):7198.

HORN FILHO, N. O. 2010. Diagnóstico geológico-geomorfológico do litoral Sul ou setor 5 do Plano Estadual de Gerenciamento Costeiro de Santa Catarina - 
GERCO/SC. Florianópolis: Governo do Estado de Santa Catarina e AMBIENS Consultoria e Projetos Ambientais. p.176-222.

HORN FILHO, N.O. \& FELIX, A. 2016. (Eds.). Atlas geológico da planície costeira do estado de Santa Catarina em base ao estudo dos depósitos quaternários. Série mapas IBGE - Mapa n³. Escala 1:100.000. Florianópolis: UFSC/CFH (Departamento de Geociências e Programa de Pós-graduação em Geografia), CNPq. (no prelo).

HESP, P. A. \& SHORT, A. D. 1999. Barrier morphodynamics. In: SHORT, A.D. (Ed.) Handbook of beach and shoreface morphodynamics. Chichester, Jonh Wiley \& Sons Ltda., p.307-333.

FISHER, W. L. \& McGOWEN, J. H. 1967. Depositional systems in the Wilcox Group of Texas and their relationship to occurrence of oil and gas. Gulf Coast Assoc. Geol. Socs. Trans., 17:105-125.

FISHER, W. L. \& McGOWEN, J. H. 1969. Depositional systems in Wilcox Group (Eocene) of Texas and their relation to occurence of oil and gas. Bull. Am. Assoc. Petrol. Geologists, 53(1):30-54.

FOLK, R. L.; WARD, W. C. 1957. Brazos river bar: a study in the significance of grain size parameters. Journal of Sedimentary Petrology, 27:3-27.

FREITAS, R.O. de. 1951. Ensaio sobre a tectônica moderna do Brasil. São Paulo, Fac. Fil. Ciên. Letras, USP, 120p. (Bol. 130, Geol. 6).

INTERNATIONAL COMMISSION ON STRATIGRAPHY (ICS). 2013. Tabela Cronoestratigráfica Internacional. Canadá: IUGS. 1p.

MARTIN, L.; MÖRNER, N. A.; FLEXOR, J. M.; SUGUIO, K. 1986. Fundamentos e reconstrução de antigos níveis marinhos do Quaternário. Boletim IG-USP, 4:1-161.

MORTON, R. A. 1994. Texas barriers. In: DAVIS, R. A. (Ed.) Geology of Holocene barrier island systems. Springer-Verlag, Berlin: 75-114.

ROY, P. S.; COWELL, P. J.; FERLAND, M. A.; THOM, B. G. 1994. Wave-dominated coasts. In: CARTER, R. W. G.; WOODROFFE, C. D., Coastal evolution: late Quaternary shoreline morphodynamics. Cambridge: Cambridge University Press, p.121-186.

SOUZA, C. R. G.; SOUZA FILHO, P. W. M.; ESTEVES, L. S.; VITAL, H.; DILLENBURG, S. R.; PATCHINEELEM, S. M.; ADDAD, J. E. 2005. Praias arenosas e erosão costeira. In: SOUZA, C. R. G.; SUGUIO, K.; OLIVEIRA, A. M. S; OLIVEIRA, P. E. Quaternário do Brasil. Editora Holos, Ribeirão Preto. Capítulo 7, p.130-152.

SUGUIO, K. 1973. Introdução à Sedimentologia. São Paulo, Edgard Blucher.

SUGUIO, K.; MARTIN, L.; BITTENCOURT, A. C. S. P.; DOMINGUEZ, J. M. L.; FLEXOR, J. M.; AZEVEDO, A. E. G., 1985. Flutuações do nível relativo do mar durante o Quaternário superior ao longo do litoral brasileiro e suas implicações na sedimentação costeira. Revista Brasileira de Geociências, 15:273-286. 
TOLDO JR., E. 1997. Sedimentologia I e II. Instituto de Geociências, Departamento de Mineralogia e Petrologia, UFRGS, (apostila), 89p.

VILLWOCK, J. A.; TOMAZELLI, L. J.; LOSS, E. L.; DEHNHARDT, E. A.; HORN, N. O.; BACHI, F. A. \& DEHNHARDT, B. A. 1986. Geology of the Rio Grande do Sul coastal province. In: RABASSA, J. ed. Quaternary of South America and Antarctic Peninsula. A. A. Balkema, Rotterdam. 4:79-97. 1986.

\section{NOTAS DE AUTOR}

\section{CONTRIBUIÇÃO DE AUTORIA}

Aline Pires Mateus - Concepção. Coleta de dados, Análise de dados, Elaboração do manuscrito. Norberto Olmiro Horn Filho - Revisão e aprovação da versão final do trabalho.

\section{FINANCIAMENTO}

Conselho Nacional de Desenvolvimento Científico e Tecnológico - CNPq. Número 130655/2015-5.

\section{CONSENTIMENTO DE USO DE IMAGEM}

Não se aplica.

\section{APROVAÇÃO DE COMITÊ DE ÉTICA EM PESQUISA}

Não se aplica.

\section{CONFLITO DE INTERESSES}

Não se aplica.

\section{LICENÇA DE USO}

Este artigo está licenciado sob a Licença Creative Commons CC-BY. Com essa licença você pode compartilhar, adaptar, criar para qualquer fim, desde que atribua a autoria da obra.

\section{HISTÓRICO}

Recebido em: 22-12-2016

Aprovado em: 03-02-2020 